\title{
The Resonance of Resonance: Critical Theory as a Sociology of World-Relations?
}

\author{
Simon Susen ${ }^{1}$ (iD \\ Published online: 28 March 2019 \\ (C) The Author(s) 2019, corrected publication May 2019
}

\begin{abstract}
The main purpose of this paper is to examine Hartmut Rosa's account of 'resonance'. To this end, the analysis is divided into four parts. The first part elucidates the concept of resonance, including Rosa's differentiation between horizontal, diagonal, and vertical 'axes of resonance' and their role in the construction of different 'world-relations'. The second part centres on the concept of alienation, notably the degree to which it constitutes an integral element of modern life forms and, in a larger sense, of the human condition. The third part grapples with the dialectic of resonance and alienation, shedding light on the assumption that they are antithetical to each other, while contending that their in-depth study provides normative parameters to distinguish between 'the good life' and 'the bad life'. The final part scrutinizes Rosa's attempt to defend his outline of a sociological theory of resonance against objections raised by his critics and comprises a point-by-point assessment of his plea for a resonance-focused sociology of world-relations. The paper concludes by suggesting that, notwithstanding its limitations, Rosa's approach represents one of the most promising developments in twenty-firstcentury critical theory.
\end{abstract}

Keywords Alienation - Critical theory $\cdot$ Hartmut Rosa $\cdot$ Resonance $\cdot$ Sociology of worldrelations · World-relations

The main purpose of this paper is to examine Hartmut Rosa's account of 'resonance' ${ }^{1}$, which is crucial to his outline of a Soziologie der Weltbeziehung. ${ }^{2}$ As is common with key concepts in the humanities and social sciences, there may be no accurate translation of this programmatic

\footnotetext{
${ }^{1}$ See Rosa (2016).

${ }^{2}$ See ibid., book title: Resonanz. Eine Soziologie der Weltbeziehung. On their website, the publisher (Suhrkamp) has opted for the following (somewhat cumbersome) English translation of the book's title: Resonance. A Sociology of the Relationship to the World. On the Polity website, the title appears as Resonance. A Sociology of Our Relationship to the World; see Rosa (2019 [2016]). The French title is Résonance. Une sociologie de la relation au monde; see Rosa (2018 [2016]).
}

Simon Susen

Simon.Susen@ city.ac.uk; http://www.city.ac.uk/people/academics/simon-susen

Extended author information available on the last page of the article 
label. It may be translated, literally, as 'a sociology of the relationship to the world' or, more idiomatically, as 'a sociology of world-relations'. The latter not only sounds more appropriate to a native Anglophone ear than the former, but also captures the fact that, by definition, sociology is confronted with a multiplicity of world-relations. Rosa's writings have become increasingly influential, especially in European circles. ${ }^{3}$ One of the striking aspects of his role as a 'rising star' in contemporary sociology in general and critical theory in particular is that, unlike most other 'big names' in his field of inquiry, his work is being taken seriously, and vividly discussed, not just by numerous researchers and intellectuals, but also by a diverse range of readers situated outside the epistemic sphere of academic ivory towers.

The attempt to equip critical theory with a paradigm that serves as the principal explanatory reference point for its understanding of social life is, of course, hardly new. Indeed, the entire history of critical theory is marked by 'paradigm shifts', motivated by the ambition to offer a solid foundation of socio-philosophical presuppositions on which the conceptual architecture of its diagnosis of society may be based. Irrespective of whether one considers Theodor W. Adorno's theory of negative dialectics ${ }^{4}$, Jürgen Habermas's theory of communicative action ${ }^{5}$, Axel Honneth's theory of recognition ${ }^{6}$, Rainer Forst's theory of justification ${ }^{7}$, Rahel Jaeggi's theory of life forms ${ }^{8}$, Martin Saar's theory of power ${ }^{9}$, or Rosa's theory of resonance ${ }^{10}$ —all of these approaches, regardless of their noteworthy idiosyncrasies and differences, share an interest in exploring both the empowering and the disempowering dimensions of modern societies. In this sense, notwithstanding its invaluable intellectual contributions, Rosa's attempt to develop 'a sociology of world-relations', whose core ingredient is the concept of resonance, stands firmly in the tradition of critical theory. For it reflects a continuation of the sustained effort to base critical theory on a specific paradigm, whose centrality overrides the status of all related concepts employed to uncover not only the utopian potential but also the pathological features of modernity.

In order to examine Rosa's framework, the following analysis is divided into four parts. The first part elucidates the concept of resonance, including Rosa's differentiation between horizontal, diagonal, and vertical 'axes of resonance' and their role in the construction of different 'world-relations'. The second part centres on the concept of alienation, notably the degree to which it constitutes an integral element of modern life forms and, in a larger sense, of the human condition. The third part grapples with the dialectic of resonance and alienation, shedding light on the assumption that they are antithetical to each other, while contending that their in-depth study provides normative parameters to distinguish between 'the good life' and

\footnotetext{
${ }^{3}$ See, for example: Rosa (1998, 2005, 2010, 2012), (2013 [2010]), (2015b [2005]), (2016). See also, for instance: Breidbach and Rosa (2010); Dörre et al. (2009); Dörre et al. (2015 [2010]); Kodalle and Rosa (2008); Rosa et al. (2016); Rosa and Endres (2016); Rosa et al. (2018 [2010]); Rosa and Henning (2018); Rosa et al. (2005); Rosa and Scheuerman (2009); Rosa et al. 2018b [2007/2013]). In addition, see, for example: Beljan (2017); Grigull (2014); Ketterer and Becker (2019); Kläden and Schüßler (2017); Peters and Schulz (2017); Wils (2018). There is no doubt that — not only in terms of depth and breadth, but also in terms of originality and significance-Rosa's Resonanz. Eine Soziologie der Weltbeziehung can be considered his magnum opus. Building on his previous work on alienation and acceleration, this masterpiece is Rosa's first comprehensive attempt to make a case for a renewed form of critical theory, at whose normative core lies the concept of resonance.

4 Adorno (1973 [1966]).

${ }^{5}$ Habermas 1987b [1981]) and Habermas 1987a [1981]).

${ }^{6}$ Honneth (1995 [1992]).

${ }^{7}$ Forst (2012 [2007]) and Forst (2013 [2011]).

${ }^{8}$ Jaeggi (2014) and Jaeggi (2018 [2014]).

${ }^{9}$ Saar (2007) and Saar (2013).

${ }^{10}$ Rosa (2016).
} 
'the bad life'. The final part scrutinizes Rosa's attempt to defend his outline of a sociological theory of resonance against objections raised by his critics and comprises a point-by-point assessment of his plea for a resonance-focused sociology of world-relations.

\section{Resonance}

According to Rosa, resonance can be defined as 'a form of world-relation, in which subject and world meet and transform each other' ${ }^{\prime 1}$. The emergence of resonance is possible only 'through af $\leftarrow$ fection and $\mathrm{e} \rightarrow$ motion [sic], intrinsic interest and expectation of self-efficacy $^{, 12}$, entailing the construction of a meaningful, dynamic, and transformative rapport between actors and their environment. Resonance constitutes an experiential relationship based on response, rather than echo. ${ }^{13}$ It 'presupposes that both sides speak with their own voice ${ }^{14}$, implying that every party involved in this experience enjoys a certain degree of autonomy. Furthermore, resonance hinges on 'strong evaluations ${ }^{15}$. These are not merely transactional but species-constitutive, permitting human beings to establish morally guided and mutually empowering relationships. Put differently, resonance is inextricably linked to motivational background horizons shaped by value, rather than instrumental, rationality. Finally, an essential characteristic of resonance is 'a moment of constitutive unavailability [Unverfügbarkeit]' ${ }^{16}$, indicating that its obtainability cannot be taken for granted. Its constitutive unavailability has two major implications: first, resonance cannot be brought about at will or in a purely instrumental fashion; second, resonance is unpredictable in its results.

Social relations that are sustained by resonance are an ambivalent affair: (a) They are robust because they represent an immanent force of human life. They are fragile because they can be undermined by co-existential conditions that hinder their development. (b) They are structural because they are embedded in grammars of social interaction. They are agential because they depend on people's capacity to interact with the world by relating to, working upon, and attributing meaning to the objective, normative, and subjective dimensions of their existence. (c) They are closed because they have to be sufficiently consolidated to enable those immersed in them 'to speak with their own voice' ${ }^{17}$. They are open because they have to be sufficiently adaptable to permit those experiencing them to be 'affected and reached' ${ }^{18}$ by them.

For Rosa, resonance 'is not an emotional state, but a relational mode [Beziehungsmodus]' ${ }^{19}$. It can be experienced in numerous ways, including in moments of sadness and sorrow, which is why we are able to enjoy, or even to love, sad stories. ${ }^{20}$ This relationalist understanding of the human condition stresses the socio-ontological significance of the rapports that we, as

\footnotetext{
${ }^{11}$ Ibid., p. 298.

12 Ibid., p. 298.

${ }^{13}$ See ibid., p. 298.

${ }^{14}$ Ibid., p. 298 (italics in original).

15 Ibid., p. 298 (italics added). On the concept of 'strong evaluation', see, for instance: Taylor (1976, 1985a, b), pp. 65-68 and 73-74; Taylor (1985c), pp. 220-222 and 226; Taylor (1989), pp. 4, 14, 20, 29-30, 42, 60, 63, 122, 249, 332-333, 336, 337, 383, and 514; Taylor (1995), pp. 37-39 and 59; Taylor (2011), pp. 294-295 and $297-$ 302; Taylor (2007), pp. 544 and 595. Cf. Meijer (2014) and Meijer (2018).

${ }^{16}$ Rosa (2016), p. 298.

17 Ibid., p. 298.

18 Ibid., p. 298.

${ }^{19}$ Ibid., p. 298.

${ }^{20}$ See ibid., p. 298.
} 
resonance-seeking entities, establish with different facets of our existence. Since the advent of modernity, however, the pace of life has been increasing on an unprecedented scale at various levels: socially, culturally, economically, politically, professionally, demographically, geographically, and technologically - to mention only a few aspects. This issue takes us to Rosa's principal concern:

If acceleration is the problem, then perhaps resonance is the solution. This is $[\ldots]$ the core thesis of this book. ${ }^{21}$

Whereas the former seems to move us further away from the possibility of 'the good life' [gelingendes Leben], the latter provides us with the chance of realizing it. The daily search for resonance is not motivated by the dogmatic pursuit of an ideological blueprint, let alone by the ambition to chase after a utopian end state, which may be reached at some point in the future. Rather, resonance-seeking activities form a constitutive component of everyday existence, which is inconceivable without people's desire, and need, to find meaning in their quotidian interactions with the manifold dimensions of their lifeworlds.

One need not be a 'connoisseur of the art of resonance [Resonanzkünstler]' that purposive activities are vital to people's capacity to attach value to their lives. Since human beings are longing and projecting entities, their existence is never simply about 'the given' [das Gegebene] but always also about 'the desired' [das Ersehnte]. ${ }^{23}$ This elevates relations based on resonance to the socio-ontologically privileged status of treasures of meaning, without which human life would be, at best, a dull or, at worst, a pointless affair.

Given its multilayered nature, the concept of resonance can serve as a 'potential impulse for examining world-relations in almost all fields of human life ${ }^{, 24}$ and, crucially, 'for describing the quality of [these] relations, ${ }^{25}$. It can be used as a yardstick to make judgements about the normative value of social arrangements - notably in terms of the extent to which they contribute to human empowerment. Strictly speaking, the term 'resonance' describes 'an

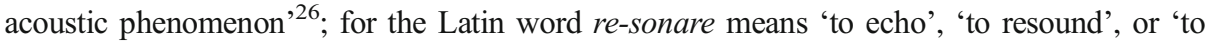
reverberate $^{, 27}$. Unlike an echo, however, resonance is not simply the product of a sequence of 'mechanic-linear reactions' ${ }^{28}$. Rather, its emergence is unthinkable without a considerable level of unpredictability, due to the relative autonomy enjoyed by the entities involved in resonance-laden activities.

'Resonance comes into being only if and when, through the vibration of one body, the frequency of another body is stimulated ${ }^{29}$ - and vice versa. In social life, resonance rests on the interaction between relatively autonomous subjects and objects. Rather than allowing for the imposition of asymmetrically structured power constellations, 'in a relation of resonance both bodies speak with their "own voice",30, thus not only affirming their relationality and reciprocity but also retaining a substantial degree of independence. Relations of resonance

\footnotetext{
${ }^{21}$ Ibid., p. 13 (italics added).

22 Ibid., p. 32.

${ }^{23}$ Cf. Susen (2007), pp. 293-296.

${ }^{24}$ Rosa (2016), p. 281.

25 Ibid., p. 281 (italics added).

26 Ibid., p. 282.

27 See ibid., p. 282.

28 Ibid., p. 282.

${ }^{29}$ Ibid., p. 282.

${ }^{30}$ Ibid., p. 282.
} 
'lead to mutual reinforcement, thereby magnifying the amplitudes of the vibrations' ${ }^{31}$ by means of which agential elements can enter into mutually fruitful modes of communication.

The typological distinction between 'synchronic resonance' ${ }^{32}$ and 'responsive resonance ${ }^{33}$, which is used to capture two ways in which bodies may interact with and react to one another, illustrates ' $[\mathrm{t}]$ he difficulty in employing this (physical) conception of resonance in relation to psychosocial world-relations ${ }^{34}$. The ontological differences between the natural world and the social world are reflected in the methodological differences between the natural sciences and the social sciences. ${ }^{35}$ In this respect, the study of resonance is no exception. Far from being tantamount to a merely factual process of physical reactions between interrelated bodies, the human search for resonance is inextricably linked to the pursuit of a meaningful life. As socio-constructive entities, equipped with the species-constitutive capacity to work upon the symbolically mediated conditions of their existence, humans create spatiotemporally contingent structures that are not only produced and reproduced but also potentially transformed by resonance-seeking practices.

In a fundamental sense, resonance is 'a mode of being-in-the-world [des In-der-Welt-Seins] - that is, a specific kind of inter-relationalization [des In-Beziehung-Tretens] ${ }^{36}$ of subjects and their environment. As 'a relational concept ${ }^{\text {'37, }}$, resonance 'describes a relationship between two (or more) objects or bodies ${ }^{38}$. In this resonance-laden relationship, each part must retain a certain grade of sovereignty. While 'responding to one another' ${ }^{39}$, all elements involved in the process 'speak with their own voice ${ }^{40}$, implying that their interaction can be understood, literally, as a dynamic of 're-sonating [zurück-tönend]' ${ }^{41}$. The coming-into-being of resonance in social life, then, presupposes not only relationality and reciprocity between two (or more) entities, but also a minimal degree of autonomy enjoyed by each of them when interacting with one another.

Given its reliance on agency, socially generated modes of resonance are irreducible to 'forms of causalist or instrumentalist ("linear") interaction [Wechselwirkung] (in the sense of mechanical entanglement [Kopplung] ${ }^{, 42}$, in which the relationship established between entities follows a predetermined - and, in principle, predictable - pattern. Rather than being determined by the laws of (natural or social) physics, processes of resonance hinge on the 'self-oscillations [Eigenschwingungen] ${ }^{43}$ emanating from agential entities, capable of articulating their 'own voice, 44 when relating to one another. Hence, we need to distinguish between resonance and echo: unlike the former, the latter does not have its 'own voice, it occurs in a mechanical way and without variation, ${ }^{45}$; what reverberates in the echo is 'only one's own

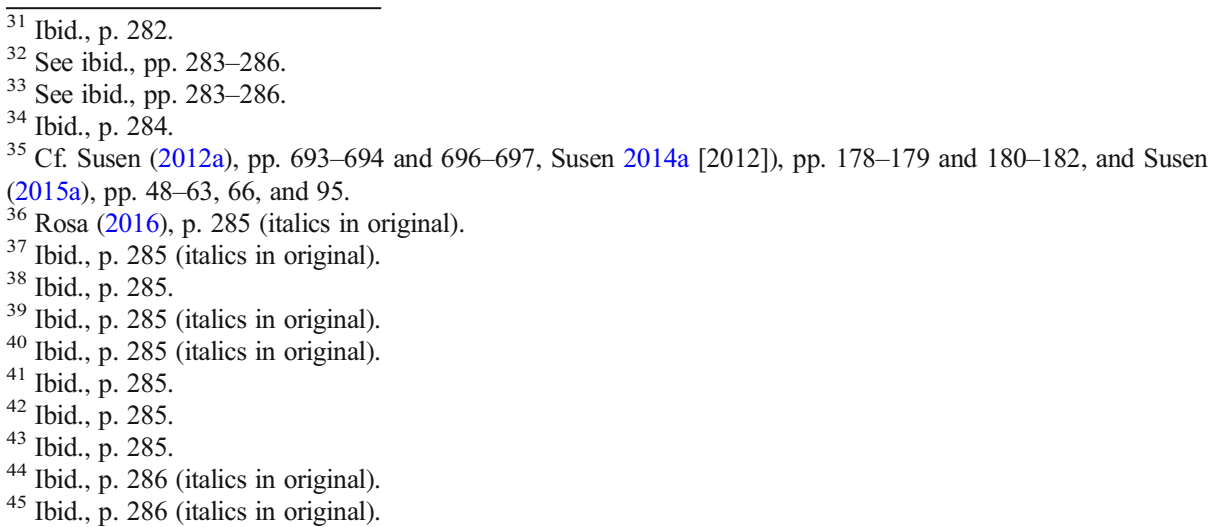


[das je Eigene], not the respondent [das Antwortende] ${ }^{46}$. Processes of resonance, by contrast, give all interacting parts the opportunity to express their own voice without being constrained by the straitjacket of natural or social determinism.

It is no accident that the concept of resonance is important in psychoanalysis and psychotherapy. In order to facilitate the construction of a fruitful space of dialogue between patient and therapist, it is necessary to create 'a space of resonance [Resonanzraum] ${ }^{47}$, in which both parties succeed in bringing about and drawing upon 'synchronic and responsive resonances ${ }^{48}$, permitting them not only to look back at [aufarbeiten] past happenings but also to make them 'reflexively accessible, objectifiable, and (possibly) workable [bearbeitbar] ${ }^{49}$ in ways that are potentially empowering for someone seeking to overcome serious personal problems.

For Rosa, the term 'resonance' is a 'key concept of a sociology of world-relations ${ }^{\text {,50 }}$. It captures 'a specific kind of world-relatedness [des Auf-die-Welt-Bezogenseins] ${ }^{\text {'51 }}$. The various positions we occupy in the social space are 'the result of previous relational conditions [Beziehungsverhältnisse] or relations [Relationen $]^{52}$, implying that the ways in which we are situated in the world are contingent upon spatiotemporally variable constellations of action and interaction. The 'being-placed-in-the-world [In-die-Welt-Gestelltsein] ${ }^{53}$ constitutes the fundamental form of immersion experienced by human subjects when exposed to the objective, normative, and subjective dimensions of their existence.

In Rosa's 'sociology of world-relations', experiences of resonance possess socioontological preponderance. Life seems pointless to humans unless its different facets 'speak to'-and, thus, 'resonate with'-them in one way or another. The 'triad of converging movements of body, mind, and the experiential world ${ }^{, 54}$ suggests that the confluence of our corporeal, mental, and immersive practices and structures allows for the emergence of resonance. '[W] here our cognitive and evaluative maps converge with our actions or being ${ }^{, 55}$, experiences of resonance, based on the 'correspondence with our strong evaluations' ${ }^{56}$, are more likely to occur. Moments of resonance tend to be marked by a homology between 'what is' and 'what ought to be', between 'objective conditions' and 'normative or subjective expectations', between 'the world as it is' and 'the reality that we construct around it ${ }^{57}$.

For Rosa, then, 'resonance' can be regarded as both a descriptive and a normative concept:

- At the descriptive level, the fact that resonance is both a basic human need and a basic human capacity has two implications.

\footnotetext{
46 Ibid., p. 286.

47 Ibid., p. 286.

48 Ibid., p. 286.

49 Ibid., p. 286.

${ }^{50}$ Ibid., p. 287.

${ }^{51}$ Ibid., p. 289 (italics in original).

52 Ibid., p. 289.

53 See ibid., p. 289.

${ }^{54}$ Ibid., p. 290.

${ }^{55}$ Ibid., p. 291.

${ }^{56}$ Ibid., p. 291.

${ }^{57}$ Cf. Luc Boltanski's distinction between 'world' (monde) and 'reality' (réalité). On this point, see, for example: Boltanski (2011 [2009]), esp. pp. 57-61; Boltanski et al. (2010), pp. 151-152, 153, and 159-163; Boltanski et al. (2014 [2010]), pp. 592-593, 595, and 602-606; Susen (2012a), pp. 701-702; Susen 2014a [2012]), esp. pp. 184 185; Susen (2017b), pp. 105-106.
} 
a. The consolidation of human subjectivity and intersubjectivity is inconceivable without resonance-laden relations. Without their immersion in responsive experiences of mutual engagement, actors are incapable of developing a sense of personhood, embedded in the construction of individual and collective identities. ${ }^{58}$

b. Human beings have a desire for resonance-laden relations. Essentially, every human desire is a desire for resonance. Our desire for resonance is no less important than our desire for recognition. To the extent that both the former and the latter may remain unfulfilled, however, they are potentially precarious. Their lack of realization may lead to serious forms of individual and/or social alienation.

- At the normative level, the concept of resonance can serve as 'a yardstick of the good life ${ }^{59}$ and, hence, 'as the criterion of a normatively oriented social philosophy' ${ }^{, 60}$. The critique of social conditions [Kritik der Gesellschaftsverhältnisse] is toothless without the critique of resonance conditions [Kritik der Resonanzverhältnisse]. ${ }^{61}$ For the quality of people's resonance-specific experiences is vital to the quality of their lives and, ultimately, to their capacity to build individual and/or collective spaces of self-realization and selftransformation.

To be clear, Rosa does not claim that 'all forms or moments of world-relation have to follow the relational logic of resonance or that all experiences of the world have to be experiences of resonance'. ${ }^{62}$ Given the potential or actual fragility of resonance, its presence cannot be taken for granted, let alone assumed to permeate, or even to dictate, every aspect of social life. The notion that all world-relations are resonance-laden overlooks the fact that all 'experiences of resonance $[\ldots]$ possess an irresolvable moment of unavailability ${ }^{63}$.

This is not to repudiate the socio-ontological centrality of resonance. Indeed, what is needed is a social phenomenology of resonance, capable of demonstrating the pivotal role it plays in the construction of everyday life. The moment something resonates with us - for instance, when falling in love with someone ${ }^{64}$ - our relationship with the world becomes meaningladen. '[L]ife seems worth living ${ }^{65}$ not only 'because the world seems worth relating to ${ }^{66}$, but also because, in our daily encounters and struggles with different aspects of our existence, the world may (or may not) resonate with us and, thus, provide sources of meaning. Without resonance-seeking activities, our lives would be pointless. We resonate, therefore we are. ${ }^{67}$

Rosa distinguishes three main axes of resonance [Resonanzachsen], to which he also refers as 'axes of world-relation' [Achsen der Weltbeziehung] and 'spheres of resonance' [Resonanzsphären]:

a. Examples of horizontal axes of resonance are the family, friendship, and politics. These are established between human actors - notably through experiences of community. ${ }^{68}$

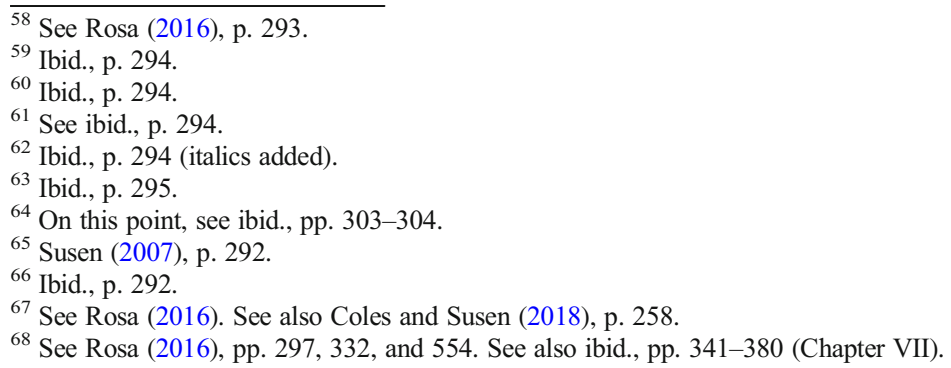


Here, the normative world of sociality 'obtains a voice ${ }^{\text {,69 }}$, illustrating the speciesconstitutive significance of meaningful interactional relations, without which human life would be devoid of intelligibility, solidarity, and identity.

b. Examples of diagonal axes of resonance are objects, work, school, sport, and consumption. These convey a connection between horizontal and vertical lines through the pursuit of purposive practices - especially when acting upon reality in a goal-oriented fashion. ${ }^{70}$ Here, the objective world of things 'obtains a voice" ${ }^{71}$, reflecting the species-generative role of human actors' capacity to define their place in the universe by constructing and reconstructing both the material and the symbolic conditions of their existence.

c. Examples of vertical axes of resonance are religion, nature, art, and history. These acquire the status of 'higher', and possibly even 'transcendent', spheres of engagement - for instance, in relation to God(s), the cosmos, time, or eternity. ${ }^{72}$ Here, the projective world of divine (or quasi-divine) beings 'obtains a voice' ${ }^{73}$, expressing a species-distinctive longing for spheres of everyday transcendence, which permit human actors to challenge the givenness of reality through the behavioural, ideological, and institutional production of teleological performance.

People who are unhappy or depressed are likely to perceive the world as 'bleak, empty, hostile, and colourless" ${ }^{74}$, while experiencing themselves and their inner world as 'cold, dead, numb, and deaf ${ }^{75}$. In such cases, "[t] he axes of resonance between self and world remain silent ${ }^{76}$. The contents of the aforementioned axes of resonance vary not only between individuals but also between cultures. ${ }^{77}$ Axes of resonance are contingent insofar as they differ in terms of the ways in which they are experienced, valorized, and problematized by individuals and cultures. Axes of resonance are universal insofar as they are experienced, valorized, and problematized by all individuals and in all cultures.

Aware of both their contingent constitution and their universal nature, critical theory needs to examine 'the social conditions that facilitate or obstruct the formation of axes of resonance ${ }^{, 78}$. For there are no emancipatory realms of existence without both individually and collectively empowering axes of resonance. Thus, the sociology of world-relations is inconceivable without 'a critique of historically realized conditions of resonance [Resonanzverhältnisse] ${ }^{79}$. It has to explore the extent to which particular sets of social constellations foster or impede the emergence of resonance-laden practices that those involved in them experience as meaningful. Faced with this ambitious task, it becomes necessary to make a case for 'a modified and renewed form of critical theory' ${ }^{80}$.

\footnotetext{
${ }^{69}$ Ibid., p. 331.

${ }^{70}$ See ibid., pp. 297, 393, 395, 420, and 554. See also ibid., pp. 381-434 (Chapter VIII).

${ }^{71}$ Ibid., p. 331.

72 See ibid., pp. 297, 419, 500, 514, and 554. See also ibid., pp. 435-514 (Chapter IX).

${ }^{73}$ Ibid., p. 331

${ }^{74}$ Ibid., p. 26.

75 Ibid., p. 26.

${ }^{76}$ Ibid., p. 26 (italics in original).

${ }^{77}$ On this point, see ibid., p. 26.

${ }^{78}$ Ibid., p. 26.

${ }^{79}$ Ibid., p. 36 (italics in original).

${ }^{80}$ Ibid., p. 36.
} 


\section{Alienation}

The concept of alienation is far from straightforward. ${ }^{81}$ In Rosa's account, alienation is the antithesis of resonance. ${ }^{82}$ Yet, whereas a large amount of literature is available on the former, the same is not true of the latter. It is no accident that the term 'alienation' occupies a central place in modern social and political thought, given that it appears to capture a crucial problem of industrial societies and, in a larger sense, of the human condition. As reflected in the abundance of analytical endeavours engaging with this concept ${ }^{83}$, however, there is hardly any consensus on its meaning, even less so on its relevance to understanding problematic aspects of advanced social formations in the twenty-first century.

For Rosa, alienation manifests itself in 'silent, cold, rigid, and failing world-relations ${ }^{84}$. It can be considered 'the result of damaged subjectivity, of resonance-hostile social and objectspecific configurations, or indeed of a discrepancy or missing correspondence between subject and world region ${ }^{85}$. Strictly speaking, alienation is inextricably linked to a sense of estrangement experienced by human beings. Alienation involves the detrimental separation of individual or collective actors from themselves as purposive entities, capable of shaping the objective, normative, and subjective dimensions of their existence. 'The silencing of all axes of resonance designates the extreme form of individual or cultural alienation at an existential level $[\ldots] .{ }^{86}$ Just as all variants of personal and social empowerment presuppose the activation of resonance, the repression of resonance by internal or external factors leads to human alienation.

From the 1970s onwards, the concept of alienation has been going through an intellectual legitimacy crisis. There has been a substantial degree of uneasiness about its use in contemporary forms of social and political analysis. ${ }^{87}$ This does not mean that the term 'alienation' is on its way out. It indicates, however, that it has lost intellectual currency. In the twentieth century, it had become a somewhat overused catchword for expressing reservations about pathological aspects of social reality. Owing to its inflationary use, the term 'alienation' has been employed to refer to almost any form of unhappiness or discontent, implying that its meaning has become increasingly vague and, possibly, too elastic for a penetrating diagnosis of social pathologies.

From Rosa's perspective, it is imperative "to define "the other" of alienation, its antithe$\operatorname{sis}^{, 88}$ - that is, the emancipatory potential of resonance. If alienation is interpreted as a 'specific mode of (world-) relationship [Modus der (Welt-) Beziehung]' ${ }^{89}$, it may be characterized as a 'relation of relationlessness [Beziehung der Beziehungslosigkeit]' ${ }^{\text {'90 }}$. Although actors may be equipped with key ingredients (such as friends, family, job, hobbies, etc.) of a seemingly rich social life, they may experience these as unsatisfying. This is why explanatory approaches that

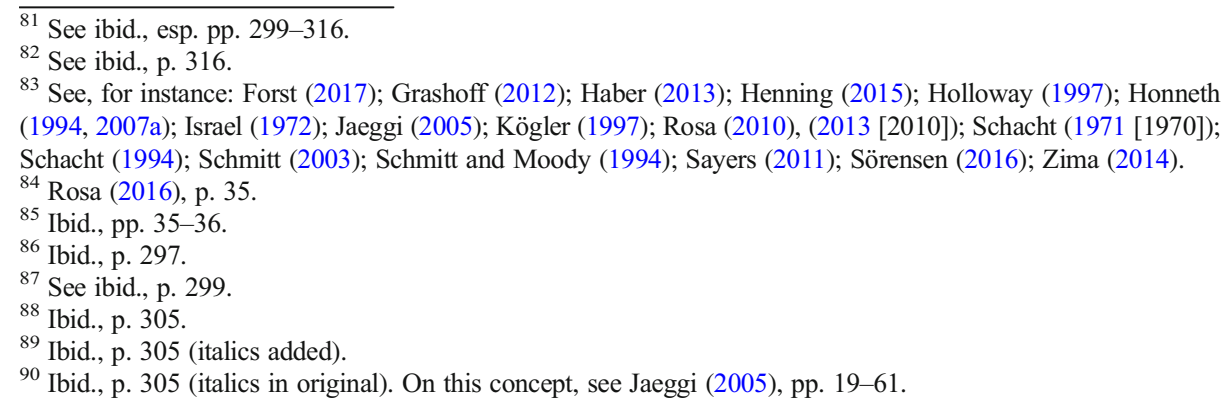


centre on the allegedly preponderant role of the struggle for resources provide little insight into the nature, causes, and consequences of human alienation. Both rationalist frameworks (such as resource mobilization and rational actor theories) and relationalist accounts (such as Bourdieu's triad of field, habitus, and capital), since they interpret 'resourcefulness' narrowly in terms of 'the accumulation of resources' 91 , fail to grasp the extent to which experiences of selfrealization and self-transformation depend on various other factors - such as the human ability to mobilize the empowering potential derived from 'axes of resonance'. In other words, access to resources is a necessary but not sufficient condition for human fulfilment.

'Relations of relationlessness' ${ }^{92}$, then, are social constellations that 'do not mean anything to us-we experience them as silent and/or hostile ${ }^{93}$. Relations of resonance, on the other hand, are social constellations that mean something to us-we experience them as fruitful and/ or responsive. Whereas alienation is based on relation-less relations [bezugslose Beziehungen], resonance is sustained by relation-laden relations [bezugsvolle Beziehungen]. The former are disempowering, preventing actors from realizing their potential; the latter are empowering, mobilizing actors towards realizing their potential. In short, the term 'alienation' designates 'a specific form of relating to the world, in which subject and world are indifferent or hostile (repulsive) to one another' ${ }^{94}$. By contrast, the term 'resonance' refers to ways of relating to the world in which the objective, normative, and subjective components of human reality are the source of genuine engagement with vital aspects of one's existence.

Under conditions of alienation, 'world adaptation [Weltanverwandlung] fails, so that the world appears cold, rigid, repelling, and non-responsive" ${ }^{95}$. Under conditions of resonance, world adaptation manifests itself in the subject's transformation, implying that one's environment is experienced as meaningful, dynamic, stimulating, and responsive. As soon as some (or all) axes of resonance become 'silent or deaf "' 'pale, dead, and empty' ${ }^{\prime 97}$. This kind of scenario is tantamount to human alienation.

\section{The Dialectic of Resonance and Alienation}

The 'dialectic of resonance and alienation'"98 lies at the heart of Rosa's argument concerning the profound ambivalence that pervades modern societies. As he spells out, ' $r$ r esonance is the other of alienation' ${ }^{99}$ and, as he adds, 'this is the core thesis of this book' ${ }^{100}$. In fact, 'resonance' and 'alienation' are Rosa's conceptual cornerstones, for his architecture of the social is based on the tension-laden relationship between these two antagonistic forces.

Rosa insists that 'resonance' is not synonymous with 'consonance' or 'harmony', just as 'alienation' is not identical to 'dissonance' or 'disharmony ${ }^{\text {,101 }}$. At first glance, 'perfection'expressed in complete order, snow-white walls, immaculate cleanliness, impeccable tidiness,

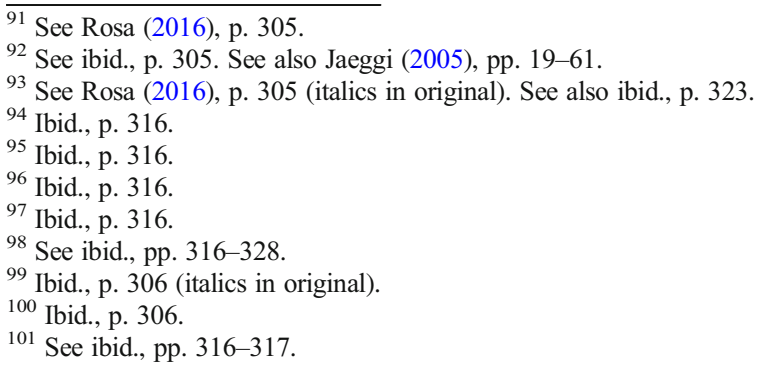


flawless functionality, or a pristine distribution of space - may appear to be indicative of 'intact, resonance-laden world-relations or robust psychological health' ${ }^{102}$. Frequently, however, the reverse is the case: veils of perfection may be symptomatic of an underlying depression, pathology, or anomie. They may 'express the (desperate) effort to keep the world or the environment pure, harmonic, and faultless ${ }^{103}$, bringing about a situation in which people's experiences of reality become sterile. ${ }^{104}$ In brief, harmony is not necessarily a sign of resonance, happiness, fulfilment, and self-realization; it may be an indication of the exact opposite.

Thus, Rosa urges us to be suspicious of 'resonance simulation' ${ }^{\text {'05, }}$, which he characterizes as 'instrumental resonance' ${ }^{106}$ and 'ideological resonance' ${ }^{107}$. 'False' forms of resonance give the misleading impression that 'the good life' may be achieved through the superficial assemblage of 'harmony on display' or through the accumulation of socially relevant resources. Yet, resonance can never be found in 'pure harmony' or depend simply on 'resourcefulness'; nor does it imply the mere 'absence of alienation'. Rather, it is 'the flaring up of hope for world adaptation [Weltanverwandlung] and response in a difficult world' ${ }^{108}$; it is the emergence of ' a connection to a source of strong evaluations in a predominantly mute, and often also repulsive, world ${ }^{109}$. Such moments may involve a deep sense of disharmony and resourcelessness, while entailing the latent presence of alienation.

Intense experiences of resonance - such as enjoying music, a sunrise or sunset, a powerful empathetic connection with a fellow human being, or the feeling of being in love - are imbued with a sense of longing for something else, a desire for something extraordinary, for a moment of transcendence within the worldly horizon of spatiotemporal immanence. These experiences 'harbour the promise of a different form of relating to the world' ${ }^{110}$ - that is, in Blochian terms, of a 'not-yet'111. This 'promise of salvation'112, although it transmits 'a hunch of deep connectedness ${ }^{113}$ between human actors and the world, reminds us of the potential 'strangeness and unavailability ${ }^{114}$ permeating social relations, especially if they are colonized by systemic imperatives, such as administrative control and profit maximization.

It would be naïve, however, to underestimate the extent to which resonance-especially those forms of resonance that are derived from the purposive, co-operative, and creative potential inherent in human work - can be (re-)appropriated by the state and the economy, ensuring it is incorporated into the cycle of material, symbolic, and financial valorization. ${ }^{115}$ Ironically, resonance can be converted into 'an instrument of reifying world-relations' ${ }^{116}$ - for instance, when it is downgraded to 'an instrument of a "successful" lifestyle in the sense of the

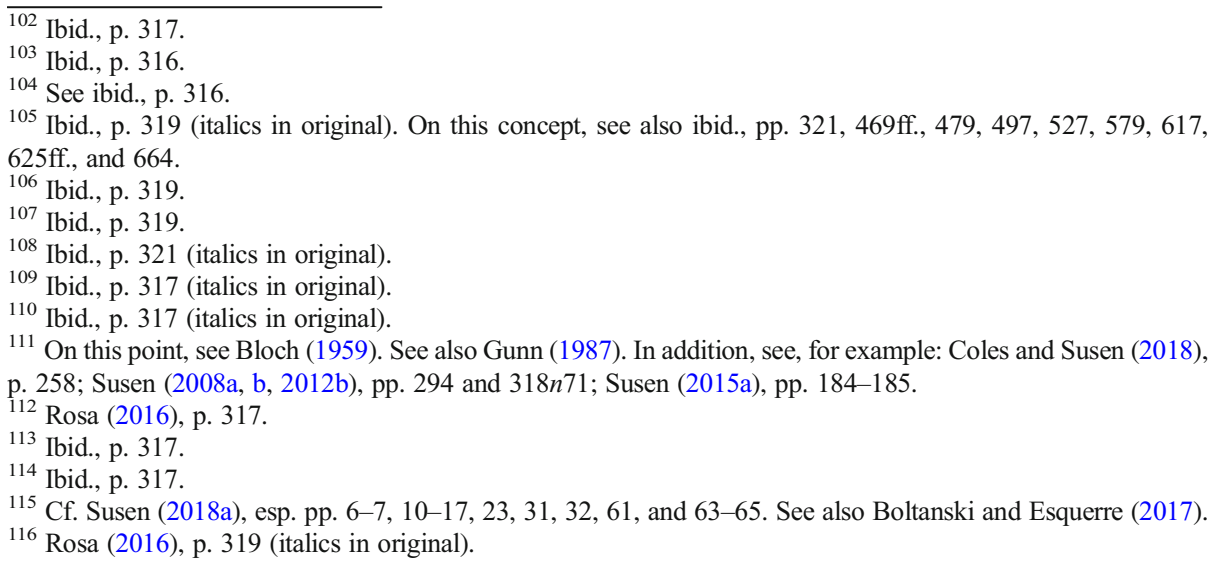


successful accumulation of resources ${ }^{117}$, permitting actors to experience instant gratification provided by consumerist 'fun societies" ${ }^{118}$ [Spaßgesellschaften].

At the root of the experience of resonance lies the cry for the unreconciled and the pain of the alienated. It has at its centre not the denial or suppression of the resisting subject, but the moment-laden, surmised certainty of a rescinding 'nonetheless'.119

People's capacity to experience resonance is inextricably linked to their sensitivity towards experiences of alienation. Despite their quasi-transcendental status in the realm of human existence, their realization is contextually variable and, thus, spatiotemporally contingent. Resonance and alienation are correlative and co-constitutive, rather than contradictory, let alone mutually exclusive. ${ }^{120}$ In a somewhat counterintuitive manner, the critique of resonance conditions [Kritik der Resonanzverhältnisse] has to focus 'not on the occurrence but on the absence of alienation' ${ }^{121}$. In many cases, people's most liberating forms of creative resonance emerge out of profound experiences of alienation, oppression, and repulsion. By virtue of their creative work, humans (for example, as writers, poets, philosophers, sociologists, painters, composers, musicians, etc.) articulate the dialectic of resonance and alienation, which shapes every aspect of their existence.

Paradoxically, then, alienation can be both an obstacle to and a reason for resonance-laden practices, such as creative work. Just as 'resonance is possible only against the background of an other that remains alien and silent ${ }^{122}$, alienation occurs only against the background of an other that provides a dynamic counterforce of resilience and empowerment. A largely implicit, unconscious, and antecedent 'dispositional trust in resonance [Resonanzvertrauen]' ${ }^{123}$ is a precondition for people's capacity to relate to, to interact with, to work upon, and to transform their existence in accordance with their needs, reflections, and desires. The species-constitutive search for 'depth-resonance [Tiefenresonanz]' 124 is a sine qua non of all human encounters with the world, including those that may be characterized as 'mute', 'repulsive', or 'alienating'.

Unsurprisingly, postmodernist and poststructuralist approaches, given their 'incredulity towards metanarratives' ${ }^{125}$, are sceptical of the possibility of 'overcoming alienation and establishing conditions of resonance ${ }^{126}$ in an emancipatory fashion. From their perspective, such an endeavour represents just another variant of 'appropriation', which, ultimately, forces 'the other' - including, for instance, marginalized and subaltern groups - to assimilate to, and to be governed by, the hegemonic modus operandi. Rosa contends, however, that it is crucial to draw a distinction between 'adaptation' [Anverwandlung] and 'appropriation' [Aneignung]. Unlike the latter, the former refers to 'the liquefaction of world conditions and relations, not their fixation; it implies the possibility of both the renewal and the transformation of subject and world and, hence, also: the possibility of a genuine encounter with the other and the

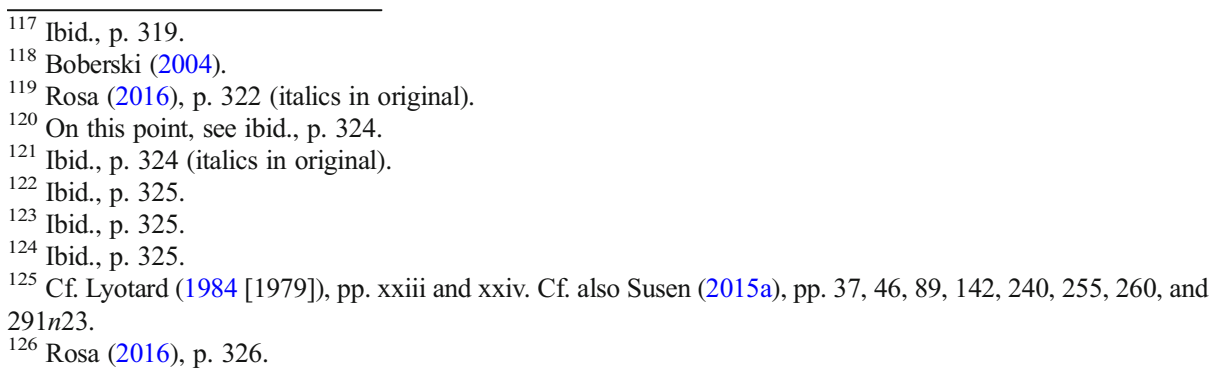


stranger, ${ }^{127}$. In other words, 'world adaptation' [Weltanverwandlung] presupposes the contingency of reality, including the constant negotiation and renegotiation of subject positions. Resonance is about openness, inclusion, and empowerment, while allowing for the possibility of contradiction, dissent, and opposition. To move from the mechanical sphere of echo to the contingent realm of resonance means to accept the power of unpredictability emanating from human agency.

The dominant form of being-in-the-world one encounters in technologically advanced societies is associated with unprecedented levels of acceleration in virtually every compartment of our lives. The tendency to colonize almost 'all (spontaneously) emerging breathing space with obligations and activities ${ }^{\prime 28}$ - for example, by elevating endless to-do-lists to the ultimate raison d'etre of late-modern life forms - is symptomatic of a widespread social pathology associated with 'task-fetishism', which prioritizes instrumental rationality over value rationality, reflecting an obsession with means over a critical engagement with ends. Detrimental trends of this kind may prevent us from realizing that, often, 'less is more' and that, contrary to the hegemonic doxa of managerialist productivism, the compulsive pursuit of innumerable targets is not the secret to living a fulfilled life. For Rosa, the only way out of this impasse is the route called 'resonance'.

\section{Critical Reflections on Key Issues}

Let us consider some key issues arising from Rosa's plea for a resonance-theoretic sociology of world-relations. Illuminating in this respect is his 'defence of resonance theory against its critics' ${ }^{129}$ — an endeavour that expresses, in his words, 'optimism against the sceptics ${ }^{130}$. This undertaking is motivated by two major convictions: first, the diagnostic conviction that, in the current era, 'conditions of resonance are disturbed"131, indicating that ' $[\mathrm{m}]$ odernity is out of tune ${ }^{132}$; second, the normative conviction that 'a different way of being-in-the-world, a different form of world-relation, is possible ${ }^{133}$. Admittedly, Rosa's framework is based on 'an optimistic credo, ${ }^{134}$. Rejecting the fatalistic notion that 'the basic fear of the world's lapsing into silence [Weltverstummen] ${ }^{135}$ permeates virtually every facet of modernity, Rosa insists that there are good reasons to have confidence in 'its cardinal promise for a meaningful form of being-in-theworld [eine gelingende Form des Daseins] ${ }^{136}$. Built into modernity, on this account, is a fundamental 'hope for resonance [Resonanzhoffnung] ${ }^{137}$, which has led to 'the intensification of longing for resonance [Resonanzverlangen] ${ }^{138}$ and manifests itself in 'the search for a better form of being-in-the-world [Daseinsform] ${ }^{139}$. Having acknowledged Rosa's firm belief in the possibility of 'the good life', let us reflect on his defence of resonance theory.

\footnotetext{
127 Ibid., p. 326.

128 Ibid., p. 327.

129 See ibid., pp. 739-762.

130 Ibid., p. 739.

131 Ibid., p. 739 (italics added).

132 Ibid., p. 739 (italics in original).

133 Ibid., p. 739 (italics in original).

134 Ibid., p. 739.

135 Ibid., p. 739.

136 Ibid., p. 739.

137 Ibid., p. 739.

138 Ibid., p. 739.

139 Ibid., p. 740.
} 


\section{No Alternative?}

A central issue with which critical theorists have been grappling for some time is the question of whether or not there is any possibility of developing genuinely alternative life forms, capable of overcoming the stifling logic of social domination. The ubiquitous 'reification of the world' [Welt-Verdinglichung] and the insidious 'context of total delusion' [totaler Verblendungszusammenhang] appear to prevent human actors from grasping the pathological dynamics by which their lives are governed. It seems that there is no room for emancipation if the transformative power of sublation [Aufhebung] is trumped by the conservative force of perpetual preservation [Aufrechterhaltung].

Challenging such a pessimistic outlook, Rosa asserts that '[s]ubjects are not totally alienated and deluded ${ }^{140}$. If that were the case, they would not be able to function as fully fledged members of the social world. Subjects cannot be entirely estranged and duped because 'they are always already immersed in relations of resonance and even emerge from them ${ }^{141}$. Resonance is not one among many other world-relations; rather, it is the human worldrelation par excellence - that is, it is 'the primary world-relation from which the subject and the experiential world arise as empirical facts [Erfahrungstatsachen $]^{142}$. The human being-inthe-world [Dasein] hinges on the incessant construction and reconstruction of resonance-laden worlds [Resonanzwelten]. Surely, the 'reification of resonance [Resonanzverdinglichung] ${ }^{143}$ is a worrying feature of capitalist societies, in which, by virtue of integrationist techniques that are strategically employed in the labour market, 'empathetic and enthusiastic capacities are economized as productive resources ${ }^{144}$. Notwithstanding the pervasive force of quasiubiquitous commodification processes in advanced capitalist formations, human beings continue to have a strong desire for experiencing genuinely enriching modes of resonance, whose authenticity transcends the limited horizon of systemic immanence.

Reflection 1: Broadly speaking, Rosa's insistence on the possibility of establishing emancipatory life forms may be justified. More specifically, Rosa convincingly characterizes resonance as 'a relational mode [Beziehungsmodus] ${ }^{145}$. Throughout his book, he underscores that he is making a case for a Soziologie der Weltbeziehung. It may be useful, however, to distinguish between Weltbeziehung and Weltbezug. The former emphasizes both the processual and the structural constitution of world-relations. ${ }^{146}$ The latter stresses both the situational and the contingent constitution of world-relations. ${ }^{147}$ Arguably, 'a sociology of Weltbeziehung' is as important as 'a sociology of Weltbezug'. To be exact, both labels should contain the plural,

\footnotetext{
140 Ibid., p. 740 .

141 Ibid., p. 740.

142 Ibid., p. 741.

143 Ibid., p. 741.

144 Ibid., p. 741.

145 Ibid., p. 298.

${ }^{146}$ In German, the word 'Beziehung' tends to be used to emphasize both the processual and the structural constitution of world-relations. For instance, the phrase 'in einer Beziehung sein' means 'to be in a relationship', which is both processual, in the sense that it is constantly developing, and structural, in the sense that it is based on more or less solidified (and explicitly or implicitly recognized) normative expectations, conventions, and arrangements.

${ }^{147}$ In German, the word 'Bezug' tends to be used to stress both the situational and the contingent constitution of world-relations. For example, the idiom 'keinen Bezug zu etwas (oder zu jemandem) haben' means 'not to be able to relate to something (or to somebody)', which is both situational, in the sense that this experience is situated in a particular setting, and contingent, in the sense that this experience may change depending on the circumstances in which one finds oneself.
} 
indicating that human life is built upon numerous Weltbeziehungen and Weltbezüge. What is needed, then, is 'a sociology of Weltbeziehungen and Weltbezüge', capable of exploring the manifold ways in which human actors relate to their environments and, ultimately, to themselves. We form Weltbeziehungen, which are anchored in our axes of resonance, enabling us to construct relatively stable and predictable relationships. At the same time, we rely on daily Weltbezüge, by means of which we attribute meaning to the world in spatiotemporally variable contexts. There are no Weltbeziehungen without Weltbezüge, for we can build axes of resonance - including solid social bonds - only insofar as we can relate to something. There are no Weltbezüge without Weltbeziehungen, for we can relate to something - no matter how cursorily and ephemerally - only insofar as we are embedded in already existing, and always potentially shifting, axes of resonance. Any search for emancipatory life forms needs to draw its resonance-laden resources from the ineluctable dialectic of Weltbeziehungen and Weltbezüge.

\section{No Alienation?}

For Rosa, alienation is inextricably linked to the absence, or at least the interruption, of resonance. Alienation may be defined as 'an objectifying "cold" disengagement ${ }^{148}$, involving a person's disenchantment with particular aspects of the world. The very possibility of alienation presupposes that subjects are able to suspend resonance when they find themselves caught up in circumstances that prevent them from exercising empowering degrees of purposive autonomy. The capacity for non-compliance constitutes a cultural technique [Kulturtechnik] that is worth defending, since it allows actors to avoid relationships that they perceive as alienating and, hence, as devoid of resonance. The ability to be non-compliant by not providing resonance if and when actors wish to do so is 'a cardinal, indispensable capacity ${ }^{149}$. It permits them to draw upon the normative parameters upon which their beliefs and actions are based when navigating their way through the social world.

Experiences of alienation, then, cannot be dissociated from 'the capacity to disrupt or to eradicate [stilllegen] resonances' ${ }^{150}$. Just as humans have a 'basic right to resonance realization' [Grundrecht auf Resonanzverwirklichung], they have a 'basic right to resonance denial' [Grundrecht auf Resonanzverweigerung]. ${ }^{151}$ Sustained social interaction is inconceivable without 'dispositional resonance' and 'resonance reassurance', giving actors the opportunity to participate in the construction of everyday life by cultivating an 'open dialogical attitude ${ }^{, 152}$. Alienation occurs, however, when actors refuse to engage with their environment in a resonance-seeking, and thus meaningful, fashion.

To be clear, alienation forms an integral component of modern society. In fact, technological progress is impossible without some degree of human alienation. It would be misleading to overlook 'the massive achievements of the natural sciences and technology'153, which have significantly contributed to civilizational developments, notably the enhancement of life quality for large parts of the world population. Notwithstanding the high degrees of reification that it may have generated, technological progress has created the preconditions for providing

\footnotetext{
148 Ibid., p. 741.

149 Ibid., p. 741.

150 Ibid., p. 741.

151 Ibid., p. 741.

152 Ibid., p. 742.

153 Ibid., p. 741.
} 
'resonant world conditions for everybody ${ }^{154}$, resulting in a better distribution of resources and improving life quality for an ever larger amount of people.

From Rosa's perspective, therefore, 'mute' world-relations are not only unavoidable but also, in many cases, necessary or even desirable - as, for instance, in science and technology. Just as individuals possess the right to resonance negation, the construction of highly differentiated societies is unthinkable without the emergence of institutionalized forms of nonresonant world-relations. To put it bluntly, alienation is the price we pay for civilizationalincluding scientific and technological—developments.

Reflection 2: The issue of alienation is a highly complicated one. What gives critical theorists ('the enlighteners') the epistemic authority to tell ordinary people ('the to-be-enlightened') that they are alienated? The situation is even more complicated if the latter not only ignore the concerns expressed by the former but also enjoy the seemingly disempowering elements commonly associated with alienation. Obvious examples are capitalist consumerism and mass entertainment, fundamentalism and tribalism, esotericism and mysticism, hedonism and escapism, populism and authoritarianism. Who are we, as critical theorists, to affirm that those relishing these (or other) types of 'alienation' are victims of social domination?

\section{No ‘Reactionary' Resonance?}

Is Rosa right to assume that the idea of 'reactionary' resonance is a contradiction in terms? He admits that fascist societies appear to promote relations of resonance between those who are considered 'insiders' of their 'national' community. ${ }^{155} \mathrm{He}$ insists, however, that alienation is the precondition for the type of 'resonance' that these societies foster, since they are based on the systematic exclusion of those who are not regarded as fully fledged members of the 'national' community. ${ }^{156}$ This may occur on several grounds - notably on ideological grounds (discriminating against political opponents and dissidents), tribal grounds (discriminating against particular cultural, ethnic, and/or 'racial' groups), heteronormativist grounds (discriminating against lesbian, gay, bisexual, transsexual, transgender, intersex, queer, and/or asexual people), or eugenic grounds (discriminating against mentally and/or physically disabled people). On the face of it, fascist formations are equipped with 'excellent techniques of resonance ${ }^{, 157}$ and with the capacity to create 'highly effective zones of resonance" ${ }^{158}$, the sustained and systematic cultivation of which permits their political leaders to undertake the synchronization [Gleichschaltung] of society, which is characteristic of totalitarian rule.

In Rosa's social universe, however, resonance is fundamentally different from echo. The former is founded on the engagement with and inclusion of 'the other', whereas the latter is based on the suppression and exclusion of 'the Other'. The former demands mutual engagement and respect, 'dialogue between two or more autonomous entities ${ }^{\text {'59 }}$, the development of individuality through enriching experiences of sociality, and the integration of 'the other'. The latter requires 'the desire for fusion" ${ }^{160}$, the dissolution of individuality in the name of an imagined community, and the segregation, or even the elimination, of 'the Other'.

\footnotetext{
${ }^{154}$ Ibid., p. 741 (italics in original).

${ }^{155}$ Cf. Kühnl (1990 [1979]) and Kühnl (1998 [1983]).

156 See Rosa (2016), p. 742.

157 Ibid., p. 742.

158 Ibid., p. 742.

159 Ibid., p. 743 (italics in original).

${ }^{160}$ Ibid., p. 743 (italics in original).
} 
Furthermore, resonance must not be confused with consonance. The former is nourished by dialogical processes in which contradictions and dissonances are not only acceptable or tolerable but also desirable. The latter rests on the illusion of 'unity, harmony, and convergence $^{\text {'161 }}$, making it difficult, if not impossible, for individuals 'to develop their own voice ${ }^{162}$, let alone 'to engage with another voice ${ }^{\text {, }}{ }^{\text {. Fo }}$ For Rosa, therefore, transformative adaptation [Anverwandlung] is a core ingredient of resonance-rich social relations.

Reflection 3: One may sympathize with Rosa's contention that genuine resonance is, by definition, emancipatory. It is difficult, however, to ignore the fact that there are highly problematic practices that may 'resonate' with those performing them. Fascist regimes not only rely on 'resonance'-generating techniques and activities, but also provide realms of 'resonance' that their supporters experience as 'inspiring' and 'galvanizing'. The same is true of various other reactionary endeavours with which those immersed in them may identify in a resonant fashion. Unless Rosa provides solid normative foundations on which to justify the emancipatory value of particular resonance-laden practices, it is possible to characterize almost any set of agential and structural constellations as 'empowering', at least from the perspective of those endorsing them. Defensible normative grounds have to be both sufficiently broad and elastic to include a wide range of actors, activities, and arrangements and sufficiently narrow and categorical to exclude retrograde dynamics from their definitional umbrella.

\section{No ‘Negative' Resonance?}

The question of whether or not there is such a thing as 'negative' resonance is one of the most controversial issues arising from Rosa's conceptual framework. One may argue, for example, that an act of violence can be perceived as a mode of resonance - at least from the perpetrator's (and, in some cases, even from the victim's) perspective. In a similar vein, one may contend that repulsion - to the degree that, in a pathological sense, it may reflect an emotional state enjoyed by some people - can be interpreted as a mode of resonance. According to Rosa, however, relations sustained by resonance involve 'a generally positive form of encounter with the world ${ }^{164}$, whereas relations damaged by alienation trigger 'experiences of indifference or experiences of repulsion, 165 .

Rosa is not willing to draw a distinction between 'indifference' and 'negative or positive resonance ${ }^{166}$. For, in his eyes, 'negative resonance' is an oxymoron - that is, resonance is conceivable only as a positive experience. Given its socially contingent constitution, 'dispositional resonance is an attitude that consciously accepts vulnerability and is based on openness ${ }^{\text {'167, }}$, whereas 'repulsion is a world-relation for which (inner) hardening and enclosure are essential' ${ }^{168}$. The former involves a 'reaching of the other in a dialogical sense ${ }^{, 169}$. The latter entails the emergence of 'silent world-relations' 170 and manifests itself in experiences of

\footnotetext{
161 Ibid., p. 743 .

162 Ibid., p. 743.

163 Ibid., p. 743.

164 Ibid., p. 744.

165 Ibid., p. 744 (italics in original).

166 See ibid., pp. 292 and 743-747.

${ }^{167}$ Ibid., p. 744 (italics added).

${ }^{168}$ Ibid., p. 744 (italics in original).

169 Ibid., p. 746 (italics in original).

${ }^{170}$ Ibid., p. 292 (italics in original).
} 
'alienation, 171 . When a person is forced into responding or behaving in a particular way, we leave the terrain of self-determination and enter the realm of manipulation, coercion, domination, or even - under extreme circumstances — violence. ${ }^{172}$ Violence, of course, can be structural. In late-modern societies, for instance, the structural violence exerted by 'acceleration constraints and competition pressures ${ }^{173}$ can easily result in 'resonance blockages ${ }^{174}$, preventing actors from developing fulfilling relationships with their physical and social environments and, ultimately, with themselves.

Reflection 4: Rosa's assertion that it would be erroneous to assume that, in some cases, experiences of violence are tantamount to experiences of resonance is questionable. The point is not to deny the detrimental nature of violence, but to recognize that actors — on the giving or receiving end-may perceive its exercise as a source of resonance. In sadomasochistic practices, the infliction of pain or humiliation, based on varying degrees of violence, may be experienced as a source of pleasure by those voluntarily engaging in such activities. It appears simplistic, if not patronizing, to dismiss such patterns of behaviour as lacking in resonance for those willingly involved in them.

\section{No 'Value-Free' Resonance?}

Another important question is to what extent 'resonance' can be considered a value-laden, rather than value-free, concept that, in addition to describing a core element of human life ('resonances exist'), can be used as a benchmark for the assessment of life conditions ('resonances ought to exist'). 'Resonance', then, is both a descriptive and a normative concept.

At the descriptive level, we can observe that 'human subjects and human consciousness develop in and out of relations of resonance between an experiencing centre and an encountered something, ${ }^{175}$. Immersion in resonance-laden relations is crucial to the very possibility of individual and collective development, including human flourishing. In a relationalist fashion, Rosa posits that human subjects and the world they encounter 'are always already the result of relations, not their requirement ${ }^{176}$. In fact, resonance-laden relations are present in our lives even before we are born. 'A baby, and perhaps even an embryo, experiences and lives in resonance, long before it is able to say "I"; indeed, it learns to do the latter only through the former." ${ }^{177}$ The development of our physical integrity - including our main organs - cannot be dissociated from access to experiences of resonance. As demonstrated in neurological studies, the brain is essentially 'a relational organ' ${ }^{\text {,78, }}$, without which humans would not be able to experience resonance. Resonance, far from constituting a metaphysical affair, 'is an emotional, a neuronal and, above all, a thoroughgoingly physical reality' ${ }^{179}$. It is the primary way in which humans relate to the world. Notwithstanding its universal nature, relations of resonance cannot be divorced from the particular circumstances in which they are embedded, and vice versa. 'All culturally established life forms result from relations of resonance in specific realms of the world. In this sense, reified, silent, and distancing world-relations are the product of social and cultural learning;

\footnotetext{
171 See ibid., p. 292.

${ }_{172}$ Cf. Forst (2015), pp. 114, 115, 118, 119, and 124-127. Cf. also Susen (2018b), esp. pp. 16-17.

173 Rosa (2016), p. 294.

174 Ibid., p. 294.

175 Ibid., p. 747.

176 Ibid., p. 747.

177 Ibid., p. 747.

178 Ibid., p. 747.

179 Ibid., p. 747.
} 
they are a cultural technique. ${ }^{, 180}$ In short, both resonance and alienation constitute experiences that emerge out of, and in turn shape, socio-culturally contingent life forms.

At the normative level, Rosa urges us to recognize that, in essence, 'life is the search for resonance and the effort to avoid permanent alienation, ${ }^{181}$. The socio-foundational status of both resonance and alienation is no accident: just as '[h]uman beings long to experience the world in bearing, nurturing, warming, and accommodating ways and to experience themselves as operant within it, [...] they are scared of a silent, merciless world, to which they are powerlessly exposed $^{182}$. While the desire for resonance and the aversion to alienation are universal, the circumstances under which both of them are experienced are particular. Some social settings are more conducive to allowing for the realization of the former, whereas others are more likely to reinforce the presence of the latter. The key point for Rosa, however, is to accept that the concept of resonance can serve as 'the yardstick of social critique' ${ }^{\text {, }}{ }^{3}$ par excellence. On this account, the value of 'culturally and institutionally established worldrelations ${ }^{184}$ can (and should) be assessed in terms of the "quality of resonance' ${ }^{185}$ that they generate and by which they are generated. Instead of measuring life quality indirectly by reference to 'the increase in material wealth, options, and resources" ${ }^{186}$, it can (and should) be evaluated by examining the quality of world-relations - notably with regard to their capacity to promote experiences of resonance and, correspondingly, to minimize the risk of alienation. On this interpretation, 'the good life is one that is rich in experiences of resonance and in which, at the same time, stable axes of resonance are available ${ }^{187}$. In brief, the good life is a resonancerich form of existence.

Reflection 5: Rosa makes a strong case for the view that 'resonance' can be regarded as both a descriptive and a normative concept. The contention that it can serve as the yardstick of social critique, however, is, at best, problematic or, at worst, untenable. As conceded by Rosa, there are many other foundational elements of human existence - such as work, communicative action, mutual recognition, justification, and artistic expression. Arguably, these are no less central to the construction of emancipatory life forms than resonance. Another tricky issue in this respect is the question of how to measure 'the quality of world-relations' in terms of 'the quality of axes of resonance' that emerge within them. Should critical social scientists rely on objective, normative, or subjective criteria (or, indeed, a combination of these) to make accurate judgements about their quality? More importantly, what happens if these are out of sync? For instance, the criteria applied in science ('objectivity') may contradict those employed in other social fields ('normativity') and may be at odds with those mobilized by particular individuals ('subjectivity'). A resonance-focused sociology of world-relations needs to account for the potential or actual discrepancies between these levels of perception, if it seeks to provide a genuinely comprehensive understanding of the qualitative differences between 'the good life' and 'the bad life'.

\footnotetext{
180 Ibid., p. 747.

${ }^{181}$ Ibid., pp. 747-748.

182 Ibid., p. 748.

183 Ibid., p. 749 (italics added).

184 Ibid., p. 749.

185 Ibid., p. 749.

186 Ibid., p. 749.

187 Ibid., p. 749.
} 


\section{'The Good Life'?}

Faced with Rosa's 'normative monism, ${ }^{188}$, according to which 'resonance' can be considered 'a meta-criterion of the good life' ${ }^{189}$, the question arises which other dimensions are essential to human emancipation. In Rosa's view, 'a critique of the conditions of resonance' ${ }^{190}$ is more fundamental than 'a critique of the conditions of recognition [Honneth], distribution [Fraser], production [Marx] ${ }^{191}$, communication [Habermas], justification [Forst], or any other major element of human existence. Notwithstanding their respective significance, at stake is the degree to which historically variable arrangements enable or obstruct the emergence of resonance. Repressive social conditions impede the development of specific (notably cultural, political, intellectual, spiritual, physical, sexual, aesthetic, or artistic) forms of resonance. Emancipatory social conditions, by contrast, permit subjects to realize - and, crucially, to transform - themselves by building on these forms of resonance, implying they can speak with 'their own voice" ${ }^{\text {192 }}$.

The search for resonance plays a pivotal role in the construction of social life. It would be erroneous, however, to portray resonance as a quasi-transcendental resource that is always already available to human actors. The whole point of Rosa's Resonanzkritik is to insist on its potential unavailability:

The idea of ubiquitous and universal permanent resonance [Dauerresonanz] does not serve as a horizon of normative goals. Resonance occurs primarily in ephemeral experiences; its unavailability is a constitutive feature, which means that it cannot be enforced, retained, or obtained for good and all. Resonance, under the conditions of an unredeemed being-in-the-world, is only the flaring up of hope for adaptation and response in a silent world $[\ldots] .{ }^{193}$

The presence of resonance is not tantamount to some kind of permanent utopia or dogmatic pursuit of an ideological metanarrative. Rather, resonance is always potentially fragile, because the most self-fulfilled actors cannot bypass its latent unavailability. The theory of resonance 'should not be misinterpreted as a doctrine of salvation' ${ }^{194}$. In fact, alienation-understood as 'a continued existence of a non-adaptable other [Nicht anverwandelbaren Anderen] ${ }^{195}$ - is a 'precondition for the possibility of resonance" ${ }^{196}$. There is no resonance without alienation. When going through puberty, for example, the experience of alienation is a requirement for the development of 'depth resonance' [Tiefenresonanz], through which individuals learn to articulate their own voice.

Any attempt to reduce the social world to 'the dictatorship of resonance' will possess 'totalitarian and, thus, resonance-destroying characteristics' ${ }^{197}$. For Rosa, the 'right to

\footnotetext{
${ }^{188}$ Ibid., p. 749. On the pursuit of 'normative monism' or, alternatively, 'normative dualism' in critical theory, see, for instance, Fraser and Honneth (2003).

${ }_{189}$ Rosa (2016), p. 749.

190 Ibid., p. 749.

191 Ibid., p. 749.

192 Ibid., p. 750 .

193 Ibid., p. 750 (italics in original).

194 Ibid., p. 750.

195 Ibid., p. 750 (italics in original).

196 Ibid., p. 750.

197 Ibid., p. 750.
} 
resonance denial ${ }^{198}$ constitutes a 'basic human right' ${ }^{199}$ : human beings have the right to withhold their resonance if they feel alienated from a particular individual, group, or situation. 'The good life' is made up of emancipatory practices and structures in which constitutive axes of resonance can develop, allowing for 'recurrent experiences of (ephemeral, processual, and transformative) resonance ${ }^{200}$. Conversely, 'the bad life' is colonized by repressive practices and structures in which subjects are forced, or at least seduced, into living impoverished lives in which alienated and alienating world-relations predominate. In short, radical Sozialkritik needs to combine Resonanzkritik and Entfremdungskritik.

Reflection 6: Rosa's plea for a 'normative monism' is motivated by the conviction that resonance can, and should, be considered 'a meta-criterion of the good life'. Rosa accepts that several other dimensions are essential to the construction of emancipatory forms of existence. Nonetheless, his assertion that 'the good life' is not only rich in resonance-laden experiences but also capable of providing stable axes of resonance is far from unproblematic. (a) Relatively stable axes of resonance - while they are sociologically vital in generating relatively solidified, and hence both predictable and viable, life forms - may lead to overly habitualized levels of repetition, expressed in experiences of dullness and boredom. In fact, when this happens, they cease to be axes of resonance and, ironically, turn into axes of alienation. (b) Highly unstable axes of resonance - although, in the long term, they cannot produce sustainable social relations - may be a major source of inspiration, creativity, enlightenment, and emancipation, notably in moments of personal or social crisis, obliging actors to call a particular order of things into question. (c) It is far from evident on what grounds it is possible to assume that some forms of resonance are more desirable than others. In short, the idea of 'the good life' continues to be controversial - arguably, because it can never be fully realized.

\section{Measuring Resonance?}

One may legitimately ask to what extent it is possible to ensure that 'resonance' is not converted into an empty or even esoteric concept, since it is not always obvious how to distinguish between 'resonant' and 'non-resonant' states of affairs, let alone how resonance may be measured. One need not be a social constructivist to understand that evidence-based research does not necessarily provide satisfactory answers to key questions in the social sciences. This is not to deny, however, that one can illustrate ' $[t]$ he difference between dispositional resonance and dispositional alienation, ${ }^{201}$ by means of empirical — notably neuropsychological - studies. Both concepts are operationalizable, since they may be employed as definable categories representing empirical realities that can be examined and measured. Resonance - which may be expressed in a person's glowing eyes after an emotional encounter - is 'an empirical reality and not an esoteric phantasy'202. Half-jokingly, Rosa mentions the idea of developing a 'glowing-eyes-index for the definition of life quality ${ }^{203}$. The more serious point he wishes to make, however, is that 'the operationalization of resonance is empirically possible ${ }^{, 204}$ and that, correspondingly, the same applies to social-

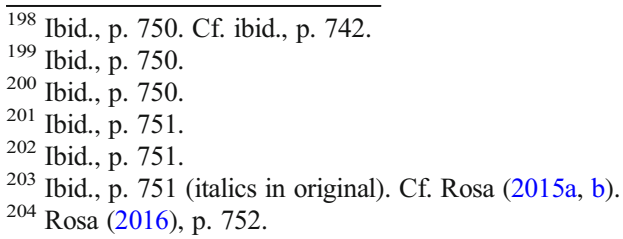


scientific research on alienation. In psychology, it is not uncommon to provide 'scales for the measurement of alienation in the sense of loss of empathy, subdued emotionality and affect, of repulsive world experience [...], lack of drive and participation, ${ }^{205}$. There is no reason why resonance and alienation cannot be explored by virtue of explanatory frameworks that are methodologically sophisticated and empirically substantiated. In short, 'resonance and alienation are [...] operationalizable concepts ${ }^{206}$.

Reflection 7: Rosa insists that resonance is operationalizable and that, consequently, it can be studied and measured scientifically. On this account, resonance-far from being reducible to a merely emotional or subjective state - constitutes an objectively existing relationship established between two (or more) entities. At the heart of his analysis, however, lies a curious paradox. On the one hand, he wishes to avoid making 'unjustified essentializations ${ }^{, 207}$, claiming that '[t]here is no need for substantialist assumptions about the true essence of human nature, ${ }^{208}$. Instead, we should, in a socio-constructivist fashion, face up to the 'historical and cultural organization and orientation [Ein- und Ausrichtung] of the world"209. On the other hand, he implicitly presupposes that there is such a thing as 'human nature'. For, presumably, our resonance-seeking orientation constitutes an anthropological invariant - that is, a foundational ontological condition that is built into all human societies and all human beings. To be alienated in resonance-theoretic terms means to be alienated from our capacity to draw on experiences, and axes, of resonance. In contemporary sociology, it may not be popular to make foundationalist assumptions about the nature of human beings. It is hard to see, however, how it is possible to defend a strong notion of alienation, let alone of resonance, without acknowledging that, as members of the same species, we share a number of essential - that is, species-constitutive-features.

\section{Ethnocentrism?}

An important question is whether or not Rosa's theory of resonance is guilty of ethnocentrism. Rosa focuses on Western spheres of resonance: family, friendship, and politics (horizontal); objects, work, school, sport, and consumption (diagonal); religion, nature, art, and history (vertical). Realms of resonance are culturally contingent. It is no surprise, therefore, that Rosa concedes that at the core of the book's diagnosis lies 'a critique of (late) modern conditions of resonance [...], on the basis of specifically Western, capitalist world-relations ${ }^{\text {,210 }}$ and that, "in this sense, it is neither historically nor transculturally universalizable ${ }^{211}$.

In his defence, Rosa maintains that many of the 'institutionalized forms of economic, political, judicial, consumerist, and scientific-technological world-relations ${ }^{212}$ to which he refers in his inquiry have, in the context of globalization, spread across the entire planet. More importantly, he asserts that a comprehensive theory of resonance is inconceivable without

\footnotetext{
205 Ibid., p. 752 (italics in original)

206 Ibid., p. 752.

207 Ibid., p. 36.

${ }^{208}$ Ibid., p. 36 (italics in original).

209 Ibid., p. 36.

210 Ibid., p. 752.

211 Ibid., p. 752.

212 Ibid., p. 752.
} 
'historical and comparative investigations of different cultural traditions and societal arrangements ${ }^{213}$. In his view, it is only by virtue of a constructive 'dialogue with other, non-European traditions ${ }^{214}$ that it is possible to appreciate 'the diversity, variability, and contingency of possible axes of resonance, ${ }^{215}$, not to mention the fact that such a cross-cultural endeavour

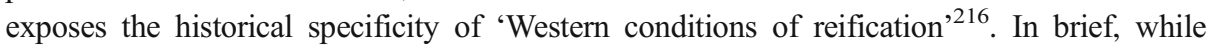
Rosa's approach does not claim to be free of ethnocentrism, it posits that a comparative, cross-cultural, and global analysis is required to account for the wide range of axes of resonance that emerge in different historical contexts.

Reflection 8: Rosa is to be applauded for admitting that his theory of resonance does not transcend the epistemic boundaries of ethnocentrism. This limitation is illustrated in Rosa's concern with typically Western spheres of resonance and in his critique of forms of alienation arising from capitalist world-relations. He rightly stresses that a comparative, cross-cultural, and global analysis is required to account for both the complexity and the diversity of axes of resonance one may encounter in different contexts across the world. What is missing from his framework, however, is a distinction between universalizable and non-universalizable aspects of resonance (and, for that matter, of alienation). As sociologists of world-relations, we need to be able to differentiate between those dimensions of resonance that exist in all societies and/or are vital to all individuals and those that exist only in some societies and/or are vital only to some individuals. The aforementioned classification of objective, normative, and subjective criteria may be valuable in this regard. Universalizable aspects of resonance are 'objective' in the sense that their factual necessity cannot be seriously denied. Non-universalizable aspects of resonance, by contrast, are 'normative' and 'subjective' in the sense that their socio-cultural contingency and personal variability are sources of differential pathways for human agency.

\section{Intersectionality?}

Another serious charge against Rosa's resonance theory is that it remains blind to the substantive differences that exist between social groups, since it presents world-relations in a holistic manner. In response to this accusation, Rosa draws attention to the subtitle of his book: Eine Soziologie der Weltbeziehung. This subtitle, he insists, emphasizes his sociological interest in the constitution of the multiple ways in which ordinary people interact with, engage with, and work upon the world by establishing relations of one sort or another. Rosa's ambition is not to explore 'the human being-in-the-world in the anthropological sense ${ }^{, 217}$. This, in his view, is a project that has already been pursued by numerous researchers - notably by phenomenological philosophers, psychologists, and neurologists. One crucial aspect of his endeavour, instead, is to shed light on the 'socially generated differences and pathologies, 218 by which people's daily immersion in the world and their contributions to its construction are shaped. Rosa proposes to interpret this fundamental facet of human life in resonance-theoretic terms.

Consider, for instance, the reproduction of social inequality in educational systems, experienced by 'the winners' as 'resonance amplifiers' and by 'the losers' as 'zones of alienation'.

\footnotetext{
213 Ibid., p. 753 .

214 Ibid., p. 753.

215 Ibid., p. 753.

216 Ibid., p. 753.

217 Ibid., p. 753.

218 Ibid., p. 753.
} 
The asymmetrical distribution of resources manifests itself in the gulf between 'dispositional resonance' and 'dispositional alienation', which is both the cause and the consequence of social inequality. ${ }^{219}$ 'Unequal opportunities of participation in the social spheres of resonance $^{, 20}$ (especially in realms such as politics, work, school, nature, and art) illustrate the degree to which patterns of stratification permeate key areas of our lives. According to Rosa, a striking example is the gendered constitution of social reality. In Western cultures, resonance sensitivity tends to be associated with 'female' and 'feminine' attributes (such as empathy, emotions, affects, and care), whereas domination tends to be linked to 'male' and 'masculine' attributes (such as rationality, instrumentality, utility, and competition). For Rosa, resonance theory and gender studies - far from being incompatible — can (and should) be cross-fertilized.

Reflection 9: Rosa notes that the asymmetrical distribution of resources manifests itself in the gulf between 'dispositional resonance' and 'dispositional alienation'. One may object, however, that his inquiry provides little in the way of an in-depth analysis of the extent to which social resources are intersectionally constituted. The contention that the uneven distribution of resonance-specific opportunities [Resonanzchancen] is both the cause [Ursache] and the consequence [Folge] of social inequality does not take us far in this respect. Most—if not all-social forces that are of major agential and/or structural significance are both causes and consequences of the historical arrangements in which they are embedded. Notwithstanding the pivotal role that resonance-specific opportunities play in terms of determining the quality of people's lives, their prospects (and, by implication, personal trajectories) are profoundly shaped by various key sociological variables - such as class, ethnicity, gender, age, and ability. Rosa's multilayered approach needs to be developed further, recognizing that resonancespecific opportunities are simultaneously contingent upon numerous sociological variables, with none of them possessing a deterministic monopoly over any other. The power of resonance hinges on the power of the social conditions by which it is reinforced or undermined.

\section{Emancipation?}

Resonance theory may appear to be anti-emancipatory, given that it tends to portray the passive quality of 'being-touched-by-something, ${ }^{221}$ as a cardinal virtue, while effectively depreciating autonomy and refusing to use it as a yardstick for the measurement of the quality of social relations. Rosa contends that this allegation is based on a misunderstanding of resonance-laden experiences. Resonance, he maintains, comprises both 'af $\leftarrow$ fection' and ' $\mathrm{e} \rightarrow$ motion' $[$ sic $] .{ }^{222}$ When experiencing resonance, we are not only touched and moved (af $\leftarrow$ fection), but also self-efficacious, meaning we are able to touch and to move someone else ( $\mathrm{e} \rightarrow$ motion). Resonance is 'by no means a passive process ${ }^{223}$. Rather, it is an active process, which requires a healthy degree of autonomy on the part of those involved in it. Rosa is wary of narrowly rationalist accounts of autonomy, 'in the sense of Kantian moral selfgovernance or even in the sense of (hedonistic, instrumental, or political) self-governance of

\footnotetext{
219 See ibid., p. 754.

220 Ibid., p. 754.

221 See ibid., p. 755

222 See ibid., p. 755.

223 Ibid., p. 755.
} 
life forms ${ }^{224}$. These rationalist frameworks are 'too one-sided and under-complex ${ }^{225}$, failing to provide a credible 'normative criterion for a good life ${ }^{226}$. The attempt to totalize such a criterion concerns a second form of misunderstanding with which Rosa takes issue.

Defending a holistic approach, Rosa affirms that '[e]xperiences of supreme achievement and happiness are always characterized by a moment of loss of autonomy,227, especially when a person is overwhelmed [überwältigt] by an idea, a piece of artistic creation, nature, or another person. Resonance contains 'a transformative element',228 that surpasses our "capacity for autonomy" ${ }^{229}$. Resonance occurs when we encounter something that 'speaks to $u s{ }^{230}$. The pursuit of autonomy, however, may undermine this transformative potential, at least if such an endeavour is motivated by the quest for 'instrumental self-efficacy in the sense of domination and control ${ }^{, 231}$. "The programme of a permanent enlargement of the world scope [Weltreichweite] ${ }^{, 232}$, which reflects the human will to exercise power, is driven by the attempt to totalize 'the desire for autonomy ${ }^{233}$, culminating in the consolidation of hegemonic practices and structures of domination. While '[s]cientific insight, technological domination, economic power further expand the spheres and possibilities of our individual and collective self-determination, ${ }^{234}$, they have not only empowering but also disempowering consequences, since they 'also harbour the danger of the world's lapsing into silence and, hence, of the loss of resonance, ${ }^{235}$. In brief, Rosa is aware of the "dialectic of Enlightenment" ${ }^{236}$ and the 'ambivalence of modernity"237.

This is not to throw the baby out with the bathwater by ignoring, let alone denying, the value of key ideals associated with the Enlightenment and modernitysuch as 'self-determination', 'sovereignty', and 'autonomy'. 'Autonomy [...] has an important, indeed central, place in the normative framework of resonance theory; yet, resonance cannot be grasped in autonomy-theoretic terms-at least not without overstretching it. ${ }^{238}$ Based on this conviction, Rosa makes a case for a normative monism, at whose core lies the concept of resonance. This option, in his view, is the most persuasive way to endorse the demand for emancipation articulated by critical theory. In this sense, the focus on resonance provides a viable alternative to the peril

\footnotetext{
224 Ibid., p. 755.

225 Ibid., p. 756.

${ }^{226}$ Ibid., pp. 755-756.

227 Ibid., p. 756.

228 Ibid., p. 756.

229 Ibid., p. 756.

${ }^{230}$ Ibid., p. 756 (italics in original).

231 Ibid., p. 756.

232 Ibid., p. 756.

233 Ibid., p. 756.

234 Ibid., p. 756.

235 Ibid., p. 756.

${ }^{236}$ Adorno and Horkheimer (1997 [1944/1969]).

237 On the ambivalence of modernity, see, for example: Bauman (1991); Bauman and Tester (2007), esp. pp. 2325 and 29; Hammond (2011), pp. 305, 310, 312, and 315; Iggers (2005 [1997]), pp. 146-147; Jacobsen and Marshman (2008), pp. 804-807; Kellner (2007), p. 117; Mulinari and Sandell (2009), p. 495; Quicke (1999), p. 281; Smart (1998); Susen (2010a), esp. pp. 62-78; Susen (2015a), pp. 1, 16-18, 190, and 236; Susen (2016a), esp. pp. 430 and 432-433; Susen (2017c), esp. pp. 104-105; Susen (2018a), pp. 36 and 66; van Raaij (1993), esp. pp. 543-546, 551-555, and 559-561.

${ }^{238}$ Rosa (2016), p. 756. On this point, see also ibid., pp. 40-42, 302ff., 305, 313-315, and 755-757.
} 
stemming from modernity's obsession with the pursuit of autonomy, which, ultimately, may undermine the conditions necessary to construct 'the good life, 239 .

Reflection 10: Rosa explicitly and unequivocally advocates what he characterizes as 'normative monism', based on the conviction that 'resonance' constitutes the foundational element of human existence par excellence. On this account, humans are essentially resonanceseeking creatures. The levels of happiness and fulfilment they can achieve depend on the quality of their experiences of resonance. A major problem with Rosa's approach, however, is that it presupposes, rather than demonstrates, the preponderance of 'healthy' resonance. According to this interpretation, all 'instrumental' forms of resonance are parasitical upon 'original' forms of resonance. Put differently, the reification of resonance [Resonanzverdinglichung] is a pathological aberration of the authentic search for the realization of resonance [Resonanzverwirklichung]. Similar to Habermas's 'ideal speech situation, ${ }^{240}$, one may imagine an 'ideal resonance situation', which-because it is not colonized by the systemic imperatives of the state and the economy - permits human actors to live fulfilling lives by releasing their emancipatory potential. The problem with this 'derivative argument', however, is that it underestimates the extent to which instrumental, strategic, and reifying dynamics are always already part of human lifeworlds - that is, before they are colonized by systemic forces. Socio-ontological romanticism, which portrays human lifeworlds as powerfree realms of pristine intersubjectivity, is no less problematic than socio-ontological fatalism, which posits that all human actions are ultimately driven by competitive struggles for power and legitimacy. A comprehensive sociology of world-relations needs to make a case for socioontological realism, which recognizes the simultaneous presence of the bright and the dark facets of humanity in all forms of sociality, notwithstanding their historical specificity. ${ }^{241}$

\section{Power?}

One may raise the question of whether Rosa's approach, at best, underestimates the significance of the unequal distribution of resources or, at worst, remains power-blind. This issue concerns the multiple ways in which spheres of resonance are permeated by power relations. Rosa concedes that a book on the relationship between power and resonance still needs to be written. ${ }^{242} \mathrm{He}$ also admits that 'power relations [...] are a constitutive component of social

\footnotetext{
239 See ibid., pp. 756-757.

240 On Habermas's concept of the 'ideal speech situation', see, for example: Habermas (1988 [1963]), pp. 279 and 281; Habermas (1970), pp. 367 and 371-374; Habermas (1990 [1983]), pp. 86-94; Habermas (2001b [1984]), pp. 85-86, 93, 97-99, and 102-103; Habermas (2001a), pp. 7-8, 10-13, 23, 29, 37, 42, 45-47, 52, and $83-84$.

${ }^{241}$ Cf., for example: Susen (2007), pp. 121-125 and 221-226; Susen (2013a), pp. 229-230; Susen (2013b), pp. $327,329,333,335,344$, and 373 .

${ }^{242}$ See Rosa (2016), p. 757. Obviously, the concern with the nature of power is a central element of contemporary social and political thought. On power and language, see, for example: Bourdieu (1992); Habermas (1987a [1981]); Habermas (1987b [1981]); Susen (2009); Susen (2013a). On power and ideology, see, for example: Boltanski (2008); Bourdieu and Boltanski (2008 [1976]); Honneth (2007b); Susen (2014b); Susen (2016c). On power and democracy, see, for example: Habermas (1996 [1992]); Ingram (2005); Pellizzoni (2001); Rosenfeld and Arato (1998); Susen (2010b), esp. pp. 103-104, 106, 110-111, and 114-117; Susen (2018c). On power and recognition, see, for example: Cusset (2003); Fraser and Honneth (2003); Honneth (1991 [1986]); Honneth (1995 [1992]); Susen (2007), pp. 192-198; van den Brink and Owen (2007); Voirol (2003). On power and justification, see, for example: Allen et al. (2014); Forst (2012 [2007]), (2013 [2011]), (2015); Haugaard (2018); Susen (2018b).
} 
reality ${ }^{243}$. A comprehensive critique of the conditions of resonance, if it is committed to uncovering and problematizing 'the reifying and alienating tendencies of social forms ${ }^{244}$, cannot shy away from the task of examining the degree to which power plays a pivotal role in the construction of any human society. For Rosa, it is clear that power and resonance are inextricably linked. In fact, given its insistence on the possibility of human emancipation, ' $[t]$ he theory of resonance aims to provide the powerless with self-efficacy',

Drawing on the works of Max Weber and Hannah Arendt, Rosa proposes to differentiate between 'power', 'domination', and 'violence'. Whereas the term 'violence' [Gewalt] designates 'a repulsive social relation, ${ }^{246}$, the terms 'power' [Macht] and 'domination' [Herrschaft] are based, at least partially, on relations of resonance. Effective systems of domination rely on the approval given by those who are being controlled, leading to a 'proto-dialogical relationship ${ }^{247}$, as famously illustrated in G. W. F. Hegel's 'master-slave dialectic ${ }^{248}$. In a Foucauldian sense, one may ask whether 'power can generate, force, or impede resonance, ${ }^{249}$. There is no doubt that violence and repression can obstruct resonance, leading to 'repulsive alienation ${ }^{250}$. In order for resonance-laden relations to emerge, people have to be able 'to love in accordance with their desires ${ }^{251}$. Resonance, then, is 'an experience that is immediately corporeal-sensory, cognitively sustained and legitimated, and transcendent ${ }^{252}$.

For Rosa, the question of whether world-relations are silent or resonant is a political one. Consider the politics of language, the politics of history, the politics of memory, or the politics of identity - all of them rest on 'resonance-specific sensibilities ${ }^{253}$ when mobilizing social actors for their respective projects. In democratic systems, 'political controversies usually take place by activating, intensifying, and instrumentalizing resonance-specific sensibilities ${ }^{254}$. Political campaigns can be successful only if they succeed in presenting themselves 'as significant for maintaining spheres of resonance ${ }^{255}$, since the transformative force of the former is derived from the motivational energy of the latter. There are no social movements without a politics of resonance [Resonanzpolitik].

Reflection 11: As argued above, a critical sociology of world-relations needs to accept that power and resonance are inextricably linked. It also needs to concede, however, that social life is shaped by numerous struggles, none of which can claim to possess the foundational status of an 'in-the-last-instance antagonism'. Struggles for resonance are vital not only to the multiple ways in which we navigate the social universe but also, in a broader sense, to macro-historical developments, which are shot through with tensions and contradictions. The same, however, applies to various other (admittedly, resonance-laden) types of struggle: social, political, sexual, economic, cultural, ethnic, religious, territorial, military, ideological, epistemic, scientific, and technological - to mention only a few. Following the principal paradigm shifts that

\footnotetext{
243 Ibid., p. 757.

244 Ibid., p. 757.

245 Ibid., p. 757 (italics in original).

246 Ibid., p. 757 (italics in original).

247 Ibid., p. 757.

248 See Hegel (1977 [1807]). See also Susen (2015b), p. 1028.

${ }^{249}$ Rosa (2016), p. 757 (italics in original).

250 Ibid., p. 757.

251 Ibid., p. 758.

252 Ibid., p. 759.

253 Ibid., p. 759.

254 Ibid., p. 759.

255 Ibid., p. 759.
} 
have been taking place in critical theory over the past decades, one may add several 'foundational' struggles to the list: the struggle for emancipation from bourgeois ideology and domination (Adorno), the struggle for deliberative democracy and undistorted communication (Habermas), the struggle for recognition (Honneth), the struggle for the right to justification (Forst), the struggle for the construction of emancipatory life forms (Jaeggi), the struggle for subverting regimes of power (Saar), and the struggle for resonance (Rosa). Considering the plurality of struggles shaping human development, the plea for a 'normative monism'-which, in Rosa's case, suggests that, ultimately, all social struggles are driven by the species-constitutive struggle for resonance - seems, at best, reductive or, at worst, monodeterministic. The fact that all social struggles are resonance-laden does not mean that all of them are resonance-driven.

\section{Apolitical?}

Critics may suggest that resonance theory is, at best, 'politically inconsequential' or, at worst, 'apolitical'. Rosa acknowledges that his sociology of world-relations does not pursue a distinct political agenda. ${ }^{256} \mathrm{He}$ contends, however, that the concept of resonance can serve as a normative compass for actors involved in contemporary political struggles, providing a benchmark for individual and collective practices. $^{257}$

A central aim of environmental politics, for instance, is to ensure that human interactions with the natural environment are not only ethically informed but also resonance-oriented. Life seems worth living only if our environment resonates with us and we resonate with our environment. This may even lead to the defence of an 'ethics of resonance [Resonanzethik]' 258 concerning all objective, normative, and subjective facets of human existence.

Another useful example is the politics of labour. In order for such a politics to be progressive, the quality of work should not be measured exclusively in terms of efficiency and productivity, let alone in terms of the profits derived from it. Rather, it should account for the fact that work constitutes one of the primary spheres of resonance, enabling humans-unless they are dominated by relations of alienation - to develop their purposive, co-operative, and creative potential. Consequently, resonance theory can be understood as an approach that is critical of, if not opposed to, capitalism, especially when faced with its profit-maximizing imperatives. ${ }^{259}$

Resonance theory supports the reconstruction of democracy. It does so by insisting that politics - far from being irreducible to 'the sphere of interest struggles, of conflict staging and the enforcement of rights, ${ }^{260}$ — can serve as 'an instrument for the adaptation of official institutions of formative background structures and of the divided lifeworld" ${ }^{261}$. Confronted with the inherent contradictions of capitalism, Rosa advocates reducing its 'competitive orientation, ${ }^{, 62}$ and introducing 'an unconditional basic income (financed through inheritance $\operatorname{tax})^{263}$. Such a radical change in direction would involve a paradigmatic shift from 'the logic of intensification', dictated by managerial strategies and market imperatives, to 'a resonance-

\footnotetext{
256 See ibid., p. 760.

257 See ibid., p. 760.

258 See ibid., p. 760 .

259 See ibid., p. 760

260 Ibid., p. 761.

261 Ibid., p. 761.

262 Ibid., p. 761.

263 Ibid., p. 761.
} 
specific sensibility', motivated by the sustained attempt to enable people to live fulfilled lives, based on dignity, solidarity, and human flourishing. ${ }^{264}$

Reflection 12: Rosa maintains that the concept of resonance can serve as a normative compass for actors involved in contemporary political struggles, providing a benchmark for individual and collective practices. The problem with this assumption, however, is that it is at once too narrow and too broad. It is too narrow in that it prioritizes 'resonance' at the exclusion of other foundational elements of social life, postulating that the former is the ultimate driving force behind the development of the latter. It is too broad in that one gets the impression that resonance is such an elastic concept that it stands for everything and nothing. Even if we share Rosa's supposition that all key aspects of human existence are pervaded by the daily search for resonance, it is not clear which particular social struggles should be prioritized to contribute to the construction of emancipatory life forms. In this respect, it may be useful to distinguish three types of field:

(a) A foundational field constitutes a civilizational ensemble of relationally structured conditions the existence of which is necessary for the emergence of social order. (b) A contingent field represents a societal ensemble of relationally structured conditions the existence of which is possible within the emergence of social order. (c) An ephemeral field stands for an interactional ensemble of relationally structured conditions the existence of which is largely irrelevant to the emergence of social order. ${ }^{265}$

Arguably, the social struggles that have shaped, and continue to shape, the course of human history are those situated in foundational fields. By contrast, those embedded in contingent and ephemeral fields are - in the grand scheme of things - less important, because they do not undergird the systems of domination by which the unequal distribution of resources is maintained. It is difficult to imagine a particular social movement, collective subject, political party, or contemporary ideology declaring that its raison d'être is 'the struggle for resonance'. This is not to deny that the search for resonance is crucial to people's lifeworlds. This is to recognize, however, that - because of, rather than despite, its quasi-ubiquitous presence in almost all aspects of social life - it is not a viable candidate for a long-term emancipatory project.

\section{Irrelevant?}

Arguably, Rosa's use of the term 'resonance' is too 'theoretical, philosophical, and abstract ${ }^{266}$. If this is the case, then its relevance to people's everyday lives appears somewhat limited. Reflecting on the validity of this objection, Rosa claims that the fundamental unavailability of resonance implies that it is impossible to capture its complexity in an exhaustive fashion. If anything, the concept of resonance 'starts crumbling if one tries to pin it down philosophical$1 y^{267}$. Since resonance comprises an 'immediate experiential reality ${ }^{\text {,268, }}$, it could hardly be more relevant to our lives. The same is true of alienation. 'Moments of resonance and

\footnotetext{
264 See ibid., p. 761.

265 Susen (2013a), p. $236 n 121$ (italics in original) (quotation modified). See also, for instance: Susen (2016b), pp. 461-463; Susen (2017a), pp. 144-146; Susen (2017b), pp. 119-120; Susen (2017d), pp. 358, 365-367, and $372 n 70$; Susen (2017e), pp. 64-65, 71, and 96n437; Susen (2018b), pp. 25-26.

266 Rosa (2016), p. 761.

${ }^{267}$ Ibid., p. 761 (italics in original).

268 Ibid., p. 761.
} 
experiences of alienation constitute poles of tension and motivational driving forces of our everyday being-in-the-world. ${ }^{269}$ The sociological centrality of resonance is illustrated in the fact that all human beings are familiar with and depend on experiences of resonance. As an anthropological invariant, resonance is an integral component of human life. All human beings function in the 'mode of dispositional resonance' ${ }^{270}$, just as they experience different degrees of 'dispositional alienation',271.

Each time a 'dispositional reluctance' 272 is triggered in us - notably when experiencing dissatisfaction, unhappiness, or rejection - we are confronted with 'loss of resonance' ${ }^{, 73}$ or at least 'disappointed resonance expectation, ${ }^{274}$. There are endless examples illustrating this kind of scenario: boredom, dull conversation, lack of interpersonal connection, a stressful job, bad weather, hopelessness, and depression - to mention only a few. Of course, people develop, and rely on, defence mechanisms when dealing with the difficult - and often unpleasantchallenges they encounter in their lives. Their 'despair mode of coping with everyday life [Alltagsbewältigungsverzweiflungsmodus] $]^{275}$ has, for many, become so prevalent that it has been normalized and, thus, elevated to their default position when grappling with everyday problems - especially when they perceive their environment as 'silent, cold, indifferent, or hostile ${ }^{276}$. For Rosa, there is no doubt, however, that 'a better world is possible ${ }^{277}$ and that, crucially, 'its principal yardstick is no longer domination and control but listening and answering, ${ }^{278}$ - that is, ultimately, not alienation but resonance.

Reflection 13: Rosa is right to insist that his resonance-focused sociology of world-relations is anchored in people's everyday experiences. The potential or actual unavailability of resonance makes the critique of social relations permeated by the detrimental force of human alienation all the more urgent. To conclude his book with the closing remark that 'a better world is possible ${ }^{279}$ and that 'its principal yardstick is no longer domination and control but listening and answering ${ }^{280}$, however, is a rather thin and disappointing ending to a major oeuvre that may be considered Rosa's masterpiece. Granted, one of the principal motivational driving forces behind critical theory is the conviction that another world is possible - that is, a social universe that is sustained not only by an equitable distribution of resources but also by people's need and drive for self-realization and self-transformation. Such an alternative world would be based on the universal interests we share as members of the same species, rather than on the particular interests we pursue as members of social groups or as individuals. In order for a critical theory of resonance to be truly emancipatory, it needs to be not only context-sensitive, accounting for the perspectival contingencies stemming from normativity and subjectivity, but also context-transcendent, committed to upholding values and principles that are universalizable in that they can be shared by all, rather than by some, members of humanity. Resonance is an essential part, but by no means the ultimate goal, of this journey.

\footnotetext{
${ }^{269}$ Ibid., p. 761 (italics in original).

270 Ibid., p. 761.

271 Ibid., p. 751.

272 Ibid., p. 761.

273 Ibid., p. 761.

274 Ibid., p. 761.

275 Ibid., p. 761.

276 Ibid., p. 762.

277 Ibid., p. 762 (italics in original).

278 Ibid., p. 762.

279 Ibid., p. 762 (italics removed).

280 Ibid., p. 762.
} 


\section{Summary}

The main purpose of this paper has been to examine Rosa's account of 'resonance'. To this end, the foregoing investigation has covered a number of key aspects arising from the in-depth analysis of his resonance-focused sociology of world-relations. The first part has elucidated the concept of resonance, drawing attention to Rosa's differentiation between horizontal, diagonal, and vertical 'axes of resonance' and their role in the construction of different 'world-relations'. The second part has clarified the concept of alienation, maintaining that it constitutes an integral element of modern life forms. The third part has explored the dialectic of resonance and alienation, especially in terms of its implications for the distinction between 'the good life' and 'the bad life'. The final part has scrutinized Rosa's attempt to defend his outline of a sociological theory of resonance against objections raised by his critics and provided a pointby-point assessment of his plea for a resonance-focused sociology of world-relations. As demonstrated in the preceding sections, Rosa has made a major, and highly original, contribution to contemporary social thought, even if one may legitimately argue that his framework suffers from significant shortcomings. Notwithstanding the limitations of his 'normative monism', there is no doubt that Rosa's resonance-focused approach, although it may not resonate with everyone, represents one of the most promising developments in twenty-firstcentury critical theory.

Acknowledgements I am immensely grateful to two anonymous reviewers for providing me with detailed, useful, and constructive comments on a draft version of this article. In addition, I would like to thank Patrick Baert for encouraging me to incorporate the changes requested by the reviewers.

Funding The author(s) received no financial support for the research, authorship, and/or publication of this article.

\section{Compliance with Ethical Standards}

Ethical Approval This article does not contain any studies with human participants or animals performed by any of the authors.

Open Access This article is distributed under the terms of the Creative Commons Attribution 4.0 International License (http://creativecommons.org/licenses/by/4.0/), which permits unrestricted use, distribution, and reproduction in any medium, provided you give appropriate credit to the original author(s) and the source, provide a link to the Creative Commons license, and indicate if changes were made.

Note All in-text translations of passages from Rosa (2016) are mine.

\section{References}

Adorno, T. W. (1973 [1966]). Negative dialectics. Trans. E. B. Ashton. London: Routledge.

Adorno, T. W. \& Horkheimer, M. (1997 [1944/1969]). Dialectic of enlightenment. Trans. J. Cumming, London: Verso.

Allen, A., Forst, R., \& Haugaard, M. (2014). Power and reason, justice and domination: A conversation. Journal of Political Power, 7(1), 7-33.

Bauman, Z. (1991). Modernity and ambivalence. Cambridge: Polity. 
Bauman, Z., \& Tester, K. (2007). On the postmodernism debate. In P. Goulimari (Ed.), Postmodernism. What moment? (pp. 22-31). Manchester: Manchester University Press.

Beljan, J. (2017). Schule als Resonanzraum und Entfremdungszone. Eine neue Perspektive auf Bildung. Weinheim: Beltz.

Bloch, E. (1959). Das Prinzip Hoffnung. Frankfurt am Main: Suhrkamp.

Boberski, H. (2004). Adieu, Spaßgesellschaft. Wollen wir uns zu Tode amüsieren? Eine Recherche. Wien/Klosterneuburg: Edition Va Bene.

Boltanski, L. (2008). Rendre la réalité inacceptable. À propos de "La production de l'idéologie dominante". Paris: Demopolis.

Boltanski, L. (2011 [2009]). On critique. A sociology of emancipation. Trans. G. Elliott. Cambridge: Polity.

Boltanski, L., \& Esquerre, A. (2017). Enrichissement. Une critique de la marchandise. Paris: Gallimard.

Boltanski, L., Rennes, J., \& Susen, S. (2010). La fragilité de la réalité. Entretien avec Luc Boltanski. Propos recueillis par Juliette Rennes et Simon Susen. Mouvements, 64, 151-166.

Boltanski, L., Rennes, J., \& Susen, S. (2014 [2010]). The fragility of reality: Luc Boltanski in conversation with Juliette Rennes and Simon Susen. In S. Susen \& B. S. Turner (Eds.), The spirit of Luc Boltanski: Essays on the 'pragmatic sociology of critique'. Trans. S. Susen (pp. 591-610). London: Anthem Press.

Bourdieu, P. (1992). Language and symbolic power. Edited and introduced by John B. Thompson, translated by G. Raymond and M. Adamson. Cambridge: Polity.

Bourdieu, P., \& Boltanski, L. (2008 [1976]). La production de l'idéologie dominante. Paris: Demopolis/Raisons d'agir.

Breidbach, O., \& Rosa, H. (Eds.). (2010). Laboratorium Aufklärung. München: Wilhelm Fink.

Coles, R., \& Susen, S. (2018). The pragmatic vision of visionary pragmatism: The challenge of radical democracy in a neoliberal world order. Contemporary Political Theory, 17(2), 250-262.

Cusset, Y. (2003). Lutter pour la reconnaissance et/ou témoigner du différend. Le mépris, entre tort et reconnaissance. In E. Renault \& Y. Sintomer (Eds.), Où en est la théorie critique ? (pp. 201-216). Paris: La Découverte.

Dörre, K., Lessenich, S., \& Rosa, H. (2009). Soziologie-Kapitalismus-Kritik. Eine Debatte. Frankfurt am Main: Suhrkamp.

Dörre, K., Lessenich, S., Rosa, H., Herrmann, J.-P., \& Balhorn, L. (2015 [2010]). Sociology, capitalism, critique. Trans. J.-P Herrmann \& Loren Balhorn. London: Verso.

Forst, R. (2012 [2007]). The right to justification. Elements of a constructivist theory of justice. Trans. J. Flynn. New York: Columbia University Press.

Forst, R. (2013 [2011]). Justification and critique. Towards a critical theory of politics. Trans. C. Cronin. Cambridge: Polity.

Forst, R. (2015). Noumenal power. Journal of Political Philosophy, 23(2), 111-127.

Forst, R. (2017). Noumenal alienation: Rousseau, Kant and Marx on the dialectics of self-determination. Kantian Review, 22(4), 523-551.

Fraser, N., \& Honneth, A. (2003). Redistribution or recognition? A political-philosophical exchange. Trans. J. Golb, J. Ingram, \& C. Wilke. London, Verso.

Grashoff, B. (2012). Entfremdung und Gattungswesen bei Marx (1843-1845). München: GRIN.

Grigull, S. (2014). Hartmut Rosa und Zygmunt Bauman im Vergleich. Zur Konzeptualisierung von Autonomie spätmoderner Subjekte. Münster: LIT.

Gunn, R. (1987). Ernst Bloch's The Principle of Hope. Edinburgh Review, 76, 90-98.

Haber, S. (2013). Penser le néocapitalisme. Vie, capital et aliénation. Paris: Les Prairies Ordinaires.

Habermas, J. (1970). Towards a theory of communicative competence. Inquiry, 13(4), 360-375.

Habermas, J. (1987a [1981]). The theory of communicative action. Volume 2: Lifeworld and system: A critique of functionalist reason. Trans. T. McCarthy. Cambridge: Polity.

Habermas, J. (1987b [1981]). The theory of communicative action. Volume 1: Reason and the rationalization of society. Trans. T. McCarthy. Cambridge: Polity.

Habermas, J. (1988 [1963]). Dogmatism, reason, and decision: On theory and praxis in our scientific civilization. In J. Habermas, Theory and practice. Trans. J. Viertel (pp. 253-282). Cambridge: Polity.

Habermas, J. (1990 [1983]). Discourse ethics: Notes on a program of philosophical justification. In J. Habermas, Moral consciousness and communicative action. Trans. C. Lenhardt \& S. Weber Nicholsen (pp. 43-115). Cambridge: MIT Press.

Habermas, J. (1996 [1992]). Between facts and norms: Contributions to a discourse theory of law and democracy. Trans. W. Rehg. Cambridge: Polity.

Habermas, J. (2001a). Kommunikatives Handeln und detranszendentalisierte Vernunft. Stuttgart: Reclam, Ditzingen. 
Habermas, J. (2001b [1984]). Truth and society: The discursive redemption of factual claims to validity. In J. Habermas, On the pragmatics of social interaction: Preliminary studies in the theory of communicative action. Trans. B. Fultner, Cambridge: Polity, pp. 85-103.

Hammond, P. (2011). Simulation and dissimulation. Journal of War and Culture Studies, 3(3), 305-318.

Haugaard, M. (2018). Justification and the four dimensions of power. Journal of Political Power, 11(1), 93-114.

Hegel, G. W. F. (1977 [1807]). Phenomenology of spirit. Trans. A. V. Miller, with analysis of the text and foreword by J. N. Findlay. Oxford: Clarendon Press.

Henning, C. (2015). Theorien der Entfremdung zur Einführung. Hamburg: Junius.

Holloway, J. (1997). A note on alienation. Historical Materialism, 1(1), 146-149.

Honneth, A. (1991 [1986]). The critique of power. Reflective stages in a critical social theory. Trans. K. Baynes. Cambridge: MIT Press.

Honneth, A. (Ed.). (1994). Pathologien des Sozialen. Die Aufgaben der Sozialphilosophie. Frankfurt am Main: Fischer.

Honneth, A. (1995 [1992]). The struggle for recognition. The moral grammar of social conflicts. Trans. J. Anderson. Cambridge: Polity.

Honneth, A. (2007a). Pathologien der Vernunft. Geschichte und Gegenwart der Kritischen Theorie. Frankfurt am Main: Suhrkamp.

Honneth, A. (2007b). Recognition as ideology. In B. van den Brink \& D. Owen (Eds.), Recognition and power: Axel Honneth and the tradition of critical social theory (pp. 323-347). Cambridge: Cambridge University Press.

Iggers, G. G. (2005 [1997]). Historiography in the twentieth century: From scientific objectivity to the postmodern challenge. New Edition, Middletown, Con.: Wesleyan University Press.

Ingram, D. (2005). Habermas and the unfinished project of democracy. Human Studies, 28(2), 223-225.

Israel, J. (1972). Der Begriff der Entfremdung. Makrosoziologische Untersuchung von Marx bis zur Soziologie der Gegenwart. Reinbek bei Hamburg: Rowohlt.

Jacobsen, M. H., \& Marshman, S. (2008). Bauman's metaphors: The poetic imagination in sociology. Current Sociology, 56(5), 798-818.

Jaeggi, R. (2005). Entfremdung. Zur Aktualität eines sozialphilosophischen Problems. Frankfurt am Main: Campus.

Jaeggi, R. (2014). Kritik von Lebensformen. Berlin: Suhrkamp.

Jaeggi, R. (2018 [2014]). Critique of forms of life. Trans. C. Cronin. Cambridge: Harvard University Press.

Kellner, D. (2007). Reappraising the postmodern: Novelties, mapping and historical narratives. In P. Goulimari (Ed.), Postmodernism. What moment? (pp. 102-126). Manchester: Manchester University Press.

Ketterer, H., \& Becker, K. (Eds.). (2019). Was stimmt nicht mit der Demokratie? Eine Debatte zwischen Klaus Dörre, Nancy Fraser, Stephan Lessenich und Hartmut Rosa. Frankfurt am Main: Suhrkamp.

Kläden, T., \& Schüßler, M. (Eds.). (2017). Zu schnell für Gott? Theologische Kontroversen zu Beschleunigung und Resonanz. Verlag Herder: Freiburg im Breisgau.

Kodalle, K.-M., \& Rosa, H. (Eds.). (2008). Rasender Stillstand. Beschleunigung des Wirklichkeitswandels: Konsequenzen und Grenzen. Würzburg: Königshausen \& Neumann.

Kögler, H.-H. (1997). Alienation as epistemological source: Reflexivity and social background after Mannheim and Bourdieu. Social Epistemology, 11(2), 141-164.

Kühnl, R. (1990 [1979]). Faschismustheorien. Ein Leitfaden. Aktualisierte Neuauflage. Heilbronn: Distel.

Kühnl, R. (1998 [1983]). Der Faschismus: Ursachen, Herrschaftsstruktur, Aktualität. Eine Einführung. 4., überarbeitete Auflage. Heilbronn: Distel.

Lyotard, J.-F. (1984 [1979]). The postmodern condition: A report on knowledge. Trans. G. Bennington \& B. Massumi, foreword by F. Jameson. Manchester: Manchester University Press.

Meijer, M. (2014). Strong evaluation and weak ontology. The predicament of Charles Taylor. International Journal of Philosophy and Theology, 75(5), 440-459.

Meijer, M. (2018). Charles Taylor's doctrine of strong evaluation. Ethics and ontology in a scientific age. London: Rowman \& Littlefield International.

Mulinari, D., \& Sandell, K. (2009). A feminist re-reading of theories of late modernity: Beck, Giddens and the location of gender. Critical Sociology, 35(4), 493-508.

Pellizzoni, L. (2001). The myth of the best argument: Power, deliberation and reason. The British Journal of Sociology, 52(1), 59-86.

Peters, C. H., \& Schulz, P. (Eds.). (2017). Resonanzen und Dissonanzen: Hartmut Rosas kritische Theorie in der Diskussion. Bielefeld: transcript Verlag.

Quicke, J. (1999). The postmodern turn: Problems and possibilities. British Journal of Sociology of Education, 20(2), 281-284.

Rosa, H. (1998). Identität und kulturelle Praxis. Politische Philosophie nach Charles Taylor. Frankfurt am Main: Campus. 
Rosa, H. (2005). Beschleunigung. Die Veränderung der Zeitstrukturen in der Moderne. Frankfurt am Main: Suhrkamp.

Rosa, H. (2010). Alienation and acceleration. Towards a critical theory of late-modern temporality. Malmö: NSU Press.

Rosa, H. (2012). Weltbeziehungen im Zeitalter der Beschleunigung. Umrisse einer neuen Gesellschaftskritik. Berlin: Suhrkamp.

Rosa, H. (2013 [2010]). Beschleunigung und Entfremdung: Entwurf einer kritischen Theorie spätmoderner Zeitlichkeit. Trans. R. Celikates. Berlin: Suhrkamp.

Rosa, H. (2015a). Die Vermessung des Glücks. Philosophie Magazin, 4, 18.

Rosa, H. (2015b [2005]). Social acceleration. A new theory of modernity. Trans. J. Trejo-Mathys. New York: Columbia University Press.

Rosa, H. (2016). Resonanz. Eine Soziologie der Weltbeziehung. Berlin: Suhrkamp.

Rosa, H. (2018 [2016]). Résonance. Une sociologie de la relation au monde. Traduit de l'allemand par S. Zilberfarb, avec la collaboration de S. Raquillet. Paris: La Découverte.

Rosa, H. (2019 [2016]). Resonance. A Sociology of Our Relationship to the World. Trans. J. Wagner, Cambridge: Polity.

Rosa, H., \& Endres, W. (2016). Resonanzpädagogik. Wenn es im Klassenzimmer knistert. Weinheim: Beltz.

Rosa, H., \& Henning, C. (Eds.). (2018). The good life beyond growth: New perspectives. London: Routledge.

Rosa, H., \& Scheuerman, W. E. (Eds.). (2009). High-speed society: Social acceleration, power, and modernity. University Park: Pennsylvania State University Press.

Rosa, H., Meyn, K.-U., \& Philipp, M. (Eds.). (2005). Bürgerbewusstsein und Demokratie in Mittel- und Osteuropa. Zum Zustand der politischen Kultur in den postsozialistischen Staaten. Jena: Glaux.

Rosa, H., Buhren, C. G., \& Endres, W. (2016). Resonanzpädagogik \& Schulleitung. Neue Impulse für die Schulentwicklung. Weinheim: Beltz.

Rosa, H., Gertenbach, L., Laux, H., \& Strecker, D. (2018a [2010]). Theorien der Gemeinschaft zur Einführung. 2. vollständig überarbeitete Auflage. Hamburg: Junius.

Rosa, H., Strecker, D., \& Kottmann, A. (2018b [2007/2013]). Soziologische Theorien. 3 ${ }^{\text {rd }}$ Edition. Konstanz: UVK.

Rosenfeld, M., \& Arato, A. (Eds.). (1998). Habermas on law and democracy: Critical exchanges. Berkeley: University of California Press.

Saar, M. (2007). Genealogie als Kritik. Geschichte und Theorie des Subjekts nach Nietzsche und Foucault. Frankfurt am Main: Campus.

Saar, M. (2013). Die Immanenz der Macht. Politische Theorie nach Spinoza. Berlin: Suhrkamp.

Sayers, S. (2011). Marx and alienation: Essays on Hegelian themes. Basingstoke: Palgrave Macmillan.

Schacht, R. (1971 [1970]). Alienation. London: Allen and Unwin.

Schacht, R. (1994). The future of alienation. Urbana: University of Illinois Press.

Schmitt, R. (2003). Alienation and freedom. Boulder: Westview Press.

Schmitt, R., \& Moody, T. E. (Eds.). (1994). Alienation and social criticism. Atlantic Highlands: Humanities Press.

Smart, B. (1998). Facing modernity: Ambivalence, reflexivity and morality. London: SAGE.

Sörensen, P. (2016). Entfremdung als Schlüsselbegriff einer kritischen Theorie der Politik. Eine Systematisierung im Ausgang von Karl Marx, Hannah Arendt und Cornelius Castoriadis. Baden-Baden: Nomos.

Susen, S. (2007). The foundations of the social: Between critical theory and reflexive sociology. Oxford: Bardwell Press.

Susen, S. (2008a). Poder y anti-poder (I-III). Erasmus: Revista para el diálogo intercultural, 10(1), 49-90.

Susen, S. (2008b). Poder y anti-poder (IV-V). Erasmus: Revista para el diálogo intercultural, 10(2), 133-180.

Susen, S. (2009). Between emancipation and domination: Habermasian reflections on the empowerment and disempowerment of the human subject. Pli: The Warwick Journal of Philosophy, 20, 80-110.

Susen, S. (2010a). Meadian reflections on the existential ambivalence of human selfhood. Studies in Social and Political Thought, 17, 62-81.

Susen, S. (2010b). Remarks on the concept of critique in Habermasian thought. Journal of Global Ethics, 6(2), 103-126.

Susen, S. (2012a). Une sociologie pragmatique de la critique est-elle possible? Quelques réflexions sur De la critique de Luc Boltanski. Revue Philosophique de Louvain, 110(4), 685-728.

Susen, S. (2012b). 'Open Marxism' against and beyond the 'Great Enclosure'? Reflections on how (not) to crack capitalism. Journal of Classical Sociology, 12(2), 281-331.

Susen, S. (2013a). Bourdieusian reflections on language: Unavoidable conditions of the real speech situation. Social Epistemology, 27(3-4), 199-246.

Susen, S. (2013b). A reply to my critics: The critical spirit of Bourdieusian language. Social Epistemology, 27(34), 323-393. 
Susen, S. (2014a [2012]). Is there such a thing as a 'pragmatic sociology of critique'? Reflections on Luc Boltanski's On critique. In S. Susen \& B. S. Turner (Eds.), The spirit of Luc Boltanski: Essays on the 'pragmatic sociology of critique'. Trans. S. Susen (pp. 173-210). London: Anthem Press.

Susen, S. (2014b). Reflections on ideology: Lessons from Pierre Bourdieu and Luc Boltanski. Thesis Eleven, 124(1), 90-113.

Susen, S. (2015a). The 'postmodern turn' in the social sciences. Basingstoke: Palgrave Macmillan.

Susen, S. (2015b). Emancipation. In M. T. Gibbons, D. Coole, E. Ellis, \& K. Ferguson (Eds.), The encyclopedia of political thought (Vol. 3, pp. 1024-1038). Chichester: Wiley-Blackwell.

Susen, S. (2016a). Further reflections on the 'postmodern turn' in the social sciences: A reply to William Outhwaite. International Journal of Politics, Culture, and Society, 29(4), 429-438.

Susen, S. (2016b). Scattered remarks on the concept of engagement: A socio-philosophical approach. Philosophy and Society, 27(2), 459-463.

Susen, S. (2016c). Towards a critical sociology of dominant ideologies: An unexpected reunion between Pierre Bourdieu and Luc Boltanski. Cultural Sociology, 10(2), 195-246.

Susen, S. (2017a). Hermeneutic Bourdieu. In L. Adkins, C. Brosnan, \& S. Threadgold (Eds.), Bourdieusian prospects (pp. 132-159). London: Routledge.

Susen, S. (2017b). Between crisis and critique: The fragile foundations of social life à la Rodrigo Cordero. Distinktion: Journal of Social Theory, 18(1), 95-124.

Susen, S. (2017c). Following the footprints of the 'postmodern turn': A reply to Gregor McLennan. European Journal of Cultural and Political Sociology, 4(1), 104-123.

Susen, S. (2017d). Remarks on the nature of justification: A socio-pragmatic perspective. In C. Cloutier, J.-P. Gond, \& B. Leca (Eds.), Justification, evaluation and critique in the study of organizations: Contributions from French Pragmatist Sociology. Book series: Research in the sociology of organizations (Vol. 52, pp. 349-381). Bingley: Emerald.

Susen, S. (2017e). Reflections on Patrick Baert's The existentialist moment: The rise of Sartre as a public intellectual. In S. Susen \& P. Baert, The sociology of intellectuals: After 'The existentialist moment' (pp. 1122). Basingstoke: Palgrave Macmillan.

Susen, S. (2018a). The economy of enrichment: Towards a new form of capitalism? Berlin Journal of Critical Theory, 2(2), 5-98.

Susen, S. (2018b). The seductive force of 'noumenal power': A new path (or impasse) for critical theory? Journal of Political Power, 11(1), 4-45.

Susen, S. (2018c). Jürgen Habermas: Between democratic deliberation and deliberative democracy. In R. Wodak \& B. Forchtner (Eds.), The Routledge handbook of language and politics (pp. 43-66). London: Routledge.

Taylor, C. (1976). Responsibility for self. In A. O. Rorty (Ed.), The identities of persons (pp. 281-299). Berkeley: University of California Press.

Taylor, C. (1985a). What is human agency? In C. Taylor, Human agency and language: Philosophical papers (Vol. 1, pp. 15-44). Cambridge: Cambridge University Press.

Taylor, C. (1985b). Self-interpreting animals. In C. Taylor, Human agency and language: Philosophical papers (Vol. 1, pp. 45-76). Cambridge: Cambridge University Press.

Taylor, C. (1985c). What's wrong with negative liberty. In C. Taylor, Philosophy and the human sciences: Philosophical papers (Vol. 2, pp. 211-229). Cambridge: Cambridge University Press.

Taylor, C. (1989). Sources of the self: The making of the modern identity. Cambridge: Cambridge University Press.

Taylor, C. (1995). Explanation and practical reason. In C. Taylor, Philosophical arguments (pp. 34-60). Cambridge: Harvard University Press.

Taylor, C. (2007). A secular age. Cambridge: Belknap Press of Harvard University Press.

Taylor, C. (2011). Disenchantment-reenchantment. In C. Taylor, Dilemmas and connections: Selected essays (pp. 287-302). Cambridge: Belknap Press of Harvard University Press.

van den Brink, B., \& Owen, D. (Eds.). (2007). Recognition and power: Axel Honneth and the tradition of critical social theory. Cambridge: Cambridge University Press.

van Raaij, W. F. (1993). Postmodern consumption. Journal of Economic Psychology, 14(3), 541-563.

Voirol, O. (2003). L'espace public et les luttes pour la reconnaissance. De Habermas à Honneth. In C. Barril, M. Carrel, J.-C. Guerrero, \& A. Márquez (Eds.), Le public en action. Usages et limites de la notion d'espace public en sciences sociales (pp. 117-137). Paris: L'Harmattan.

Wils, J.-P. (Ed.). (2018). Resonanz. Im interdisziplinären Gespräch mit Hartmut Rosa. Baden-Baden: Nomos.

Zima, P. V. (2014). Entfremdung: Pathologien der postmodernen Gesellschaft. Tübingen: Francke. 
Publisher's Note Springer Nature remains neutral with regard to jurisdictional claims in published maps and institutional affiliations.

\section{Affiliations}

\section{Simon Susen ${ }^{1}$}

1 Department of Sociology, School of Arts and Social Sciences, City, University of London, Northampton Square, London EC1V 0HB, UK 